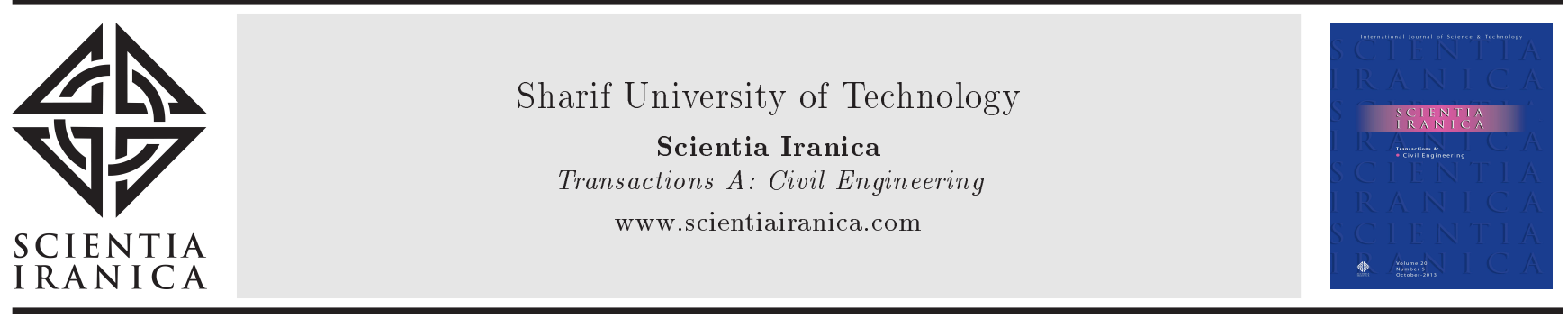

Review Article

\title{
Water reuse in Iran with an emphasis on potable reuse
}

\author{
M. Kayhanian* and G. Tchobanoglous \\ Department of Civil and Environmental Engineering, University of California, Davis, CA 95616.
}

Received 6 February 2016; received in revised form 17 March 2016; accepted 6 April 2016

KEYWORDS
Water reuse;
Potable reuse,
Indirect potable reuse;
Direct potable reuse;
Implementation;
Challenges;
Benefits.

\section{KEYWORDS}

Indirect potable reuse;

Implementation;

Benefits.

\begin{abstract}
Iran is facing a serious water crisis, which must be addressed if Iran is to move forward in becoming a developed nation. Iran's water shortage problem has been caused by multiple factors including limited surface and groundwater availability. The current water shortage in Iran is an issue that can only be resolved by considering the entire water portfolio. One alternative solution to the water shortage problem in Iran is to adapt an integrated sustainable water management system though efficient utilization of the existing water supplies including the adoption of an effective water reclamation and water reuse program. Reclaimed water could be used to augment existing water supply sources for both non-potable and potable purposes. This introductory paper is part of a series of articles documenting the use of reclaimed water for potable reuse. Topics covered in this introductory paper include: (1) an introduction to the water situation in Iran, (2) identification of the types of potable reuse, (3) presentation of successful potable reuse projects including lessons learned, (4) brief summary of key implementation components of a successful potable reuse program, and (5) special challenges and barriers on implementation of potable reuse in Iran, and (6) the benefits expected from potable reuse program in Iran. Additional information on technical aspects including operations and monitoring, and more detail information on the implementation of water reuse program will be presented in the future articles.
\end{abstract}

(C) 2016 Sharif University of Technology. All rights reserved.

\section{Introduction}

There is a serious water shortage problem in Iran. In 2015, more than 500 towns and cities across Iran struggled to meet the demand for drinking water [1]. The Energy Ministry, which is in charge of the water system, reported in March that $60 \%$ of the reservoirs of major dams were empty [1]. This water crisis is one of the main challenges Iran faces in its path to becoming a

*. Corresponding author. Tel: 530 752-8957;

Fax: 530 752-7872

E-mail addresses: mdkayhanian@ucdavis.edu (M.

Kayhanian); gtchobanoglous@ucdavis.edu (G.

Tchobanoglous) developed nation. The current water shortage problem in Iran has been caused by multiple factors, some of which may be related to mismanagement, as discussed by Madani [2], and some are related to natural causes such as climate change and persistent drought conditions in recent years.

In light of the grim facts surrounding Iran's water situation, government officials have reached the conclusion that something must be done before the issue of water scarcity becomes unmanageable. The importation of water from neighboring countries has been proposed, however this option will be very expensive and has its own limitations and problems. Importation of water is not sustainable in the long run due to safety, security, and reliability issues and, for 
this reason, is not the preferred option. An alternative solution to the water shortage problem in Iran is to adapt an integrated sustainable water management system considering the entire water portfolio including an effective water reuse program.

\subsection{Water reuse terminology}

Traditionally, water reuse terminology has been associated with the treatment and beneficial use of municipal wastewater. For example the term "water reclamation" refers to the treatment of wastewater, whereas the term "water reuse" refers to the beneficial use of the reclaimed water. The application of reclaimed water for various reuse applications including non-potable and potable reuse is dependent on the quality of the reclaimed water. To avoid confusion and because much of the terminology used in the literature is often inconsistent, the terms used in this paper related to water reuse with specific reference to potable reuse are summarized in Table 1. Although reclaimed water can also be produced from stormwater runoff recovered from rooftops and paved surfaces and greywater, these sources of water are not covered in this paper.

\subsection{Purpose of the paper}

The purpose of this first introductory paper is to introduce the subject of potable reuse to discuss briefly the special challenges associated with its implementation, and to present some of the potential benefits expected from potable water reuse. The proposed potable reuse program may help to alleviate Iran's water shortages by augmenting existing water sources. The technologies and treatment train processes that could be used to produce high quality water, including the monitoring and operational issue and implementation issues introduced briefly in this paper, will be discussed in detail in the future articles. Topics considered in this paper include: (1) an introduction to the water situation in Iran, (2) identification of the types of potable reuse, (3) presentation of successful potable reuse projects including lessons learned, (4) brief summary of key implementation components of a successful potable reuse program, (5) special challenges and barriers on implementation of potable reuse in Iran, and (6) the benefits expected from potable reuse program in Iran.

\section{Water situation in Iran}

Some background information on water situation in Iran is provided in this section including: (1) factors affecting the water shortage problem in Iran, (2) lack of an integrated water management plan in Iran, (3) strategies for developing an integrated water management plan, and (4) rationale for adapting water reuse program in Iran.

\subsection{Factors affecting water shortage problem in Iran}

Water crisis or water scarcity in Iran is the result of both physical (absolute) and economic factors. Physical water scarcity is a result of inadequate natural water resources to supply demand, and economic water scarcity is a result of poor management of the available water resources. In a recent article prepared by Madani [2], it was argued that the majority of looming water crises in Iran is due to water mismanagement. However, the impact of other factors on Iran's water shortage cannot be ignored. Low annual rainfall, continuous drought, limited water availability, population increase, inefficient water consumption in agricultural sectors, lack of long-term sustainable water management plan (water mismanagement) are among the factors contributing to the water shortage problem in Iran. The impacts of these factors on water shortage problem in Iran are reviewed briefly in Table 2 .

\subsection{Lack of integrated water management plan in Iran}

Up to now, the water management in Iran is based on the traditional non-integrated water resources management plan. The difference between the integrated and non-integrated water resources management is illustrated in Figure 1. The weakness in the traditional practice of water management, which is heavily relying on withdrawal of water from surface water reservoirs and groundwater, is that it is not site specific and not holistic. An integrated water management approach, currently lacking in Iran, is a more holistic planning method, and focuses on broader water resources management options that encompass all of the water resource systems including a water reuse element.

In addition, as shown in Figure 1, under an integrated approach, receiving waters represent surface and groundwater resources that provide both water supply sources and points of wastewater discharge. Dry weather stormwater represents low flows that occur during non-peak events that may end up in the wastewater collection system, and wet weather stormwater represents higher flow periods that generally end up as discharge to receiving waters [12]. In the non-integrated approach, water from receiving waters and watersheds areas is used as water supply source, and most of the treated wastewater and untreated stormwater is discharged into receiving water bodies. The current non-integrated water management practice in Iran could lead to the use of untreated wastewater, which may create detrimental environmental impacts (i.e., discharge of chemical pollutants, increase in algal blooms, and decrease of dissolved oxygen) in rivers and lakes.

Integrated water management significantly improves the opportunities to obtain benefits from water, 
Table 1. Definition of commonly used terminologies for water reuse program*.

\begin{tabular}{|c|c|}
\hline Terminology & Definition \\
\hline De facto reuse & $\begin{array}{l}\text { The downstream use of surface water as a source of drinking water that is subject to } \\
\text { upstream wastewater discharges (also referred as "unplanned potable reuse"). } \\
\text { This form of potable reuse is very common around the world and is usually } \\
\text { not officially recognized as a form reuse, and it is not specifically regulated. }\end{array}$ \\
\hline Direct potable reuse & $\begin{array}{l}\text { There are two forms of direct potable reuse. In the first form, advanced treated } \\
\text { water is introduced into raw water supply upstream of drinking water treatment facility. } \\
\text { In the second form, finished drinking water forms an advanced water treatment } \\
\text { facility permitted as a drinking water and is introduced directly into potable water supply } \\
\text { distribution system. Most of the current potable reuse applications are of the first form; } \\
\text { the second form is not common as obtaining the required permits is far more difficult. }\end{array}$ \\
\hline Greywater reuse & $\begin{array}{l}\text { Household wastewater captured from bathing or washing that does not contain } \\
\text { concentrated food or human waste that has been treated to meet specific water quality } \\
\text { criteria with the intent of being used for beneficial purposes. }\end{array}$ \\
\hline Indirect potable reuse & $\begin{array}{l}\text { The introduction of advanced treated water into an environment buffer such as } \\
\text { groundwater aquifer or water body before being withdrawn for potable purposes } \\
\text { (see also de facto potable reuse). Indirect potable reuse can also be accomplished } \\
\text { with tertiary effluent when applied by spreading (i.e., groundwater recharge) } \\
\text { to take advantage of soil aquifer treatment. }\end{array}$ \\
\hline Non-potable reuse & A general term for all water reuse applications, except those related to potable reuse. \\
\hline Potable reuse & $\begin{array}{l}\text { Augmentation of a drinking water supply with reclaimed water. Reclaimed or recycled } \\
\text { water \& municipal wastewater that has been treated to meet specific water } \\
\text { quality criteria with the intent of being used for beneficial purposes. }\end{array}$ \\
\hline Stormwater reuse & $\begin{array}{l}\text { Stormwater runoff captured from ground surface and rooftops that has been } \\
\text { treated to meet specific water quality criteria with the intent of being used } \\
\text { for beneficial purposes. }\end{array}$ \\
\hline Water reclamation & Treating municipal wastewater to make it acceptable for beneficial reuse. \\
\hline Water reuse & $\begin{array}{l}\text { The use of treated wastewater (reclaimed water), stormwater, and greywater } \\
\text { for a beneficial purpose. }\end{array}$ \\
\hline
\end{tabular}

* Source: Adapted from Tchobanoglous et al. [3]

regardless of the stage in the water cycle. Concepts such as integrating water conservation practices to reduce the demand for freshwater are part of this comprehensive management approach. Also, rather than viewing stormwater as a nuisance, it should be considered an asset that is allowed to recharge groundwater through Best Management Practices (BMPs), such as the use of swales, porous pavement, detention or infiltration basins. Additionally, wastewater can be reclaimed and reused, providing both environmental and water supply benefits. The end result of integrated water management is reduced discharges to receiving waters and reduced reliance on surface and groundwater supplies to meet water demands. 
Table 2. Summary review of factors affecting water shortage problem in Iran.

\begin{tabular}{|c|c|}
\hline $\begin{array}{l}\text { Contributing } \\
\text { factor }\end{array}$ & Description \\
\hline $\begin{array}{l}\text { Low annual } \\
\text { rainfall }\end{array}$ & $\begin{array}{l}\text { In numerous localities of Iran, there may be no precipitation until sudden storms, accompanied } \\
\text { by heavy rains, deliver almost the entire year's rainfall in a few days. For this reason, the water } \\
\text { shortages are compounded by the unequal distribution of precipitation throughout the country. } \\
\text { For instance, near the Caspian Sea, rainfall averages about } 1,280 \mathrm{~mm} \text { per year, but in the Central } \\
\text { Plateau and in the lowlands to the south it seldom exceeds } 100 \mathrm{~mm} \text {, and part of the country } \\
\text { receives less than } 50 \mathrm{~mm} \text { per year [4]. On average, the annual precipitation is about } 230 \mathrm{~mm} \text {. } \\
\text { About } 23 \text { percent of the rainfalls occur in spring, } 4 \text { percent in summer, } 23 \text { percent in fall and } \\
\text { the remainder } 50 \text { percent occur as snowfall during the winter season. Therefore, majority of } \\
\text { the water supply from precipitation is generated during late fall and winter. For this reason, from } \\
\text { mid spring, river and stream flowrate start to decrease and groundwater becomes the only water } \\
\text { supply source for summer and early fall seasons. }\end{array}$ \\
\hline $\begin{array}{l}\text { Drought } \\
\text { condition } \\
\text { (climate } \\
\text { change) }\end{array}$ & $\begin{array}{l}\text { Low rainfall is a natural climatologic fact for certain parts of Iran, but extreme low rainfall for } \\
\text { multiple years is most probably due to climate change. For example, in the last } 23 \text { years, there were } \\
13 \text { years of dry periods. Because of low precipitation, sensitivity of the southern parts of Iran to } \\
\text { severe drought is higher compared to other parts of the country. Therefore, low annual precipitation } \\
\text { combined with and severe drought conditions have made the water shortage crises more severe } \\
\text { in Iran. }\end{array}$ \\
\hline $\begin{array}{c}\text { Limited } \\
\text { water } \\
\text { availability }\end{array}$ & $\begin{array}{l}\text { The amount of water generated through precipitation annually is about } 417 \text { billion cubic meters } \\
\text { (bcm) in which only a small portion of it will be available as nearly } 72 \text { percent will be lost due to } \\
\text { evaporation and transpiration. Consequently, only about } 117 \mathrm{bcm} \text { of water is directly and potentially } \\
\text { accessible by people through precipitation (internal renewable resources) each year [5]. In addition, } \\
\text { about } 13 \mathrm{bcm} \text { of surface flow enters Iran from the borders of neighboring countries. Therefore, annually } \\
\text { about } 130 \mathrm{bcm} \text { of water is accessible for consumption. In addition to naturally processed water resources, } \\
\text { about } 29 \mathrm{bcm} \text { of exploited and consumed water from surface and groundwater resources appear again } \\
\text { as exploitable surface water or penetrates to alluvial aquifers as reservoirs. Correspondingly, } \\
\text { the total available water resources of Iran increase to about } 159 \text { bcm. The data obtained during } 2014 \\
\text { by the World Resource Institute (WRI) ranked Iran as the world's } 24 \text { th most water-stressed nation. } \\
\text { The WRI projected that Iran will be in a worst condition than now and will be more } \\
\text { water-stressed in the future. }\end{array}$ \\
\hline $\begin{array}{l}\text { Population } \\
\text { growth } \\
\text { with higher } \\
\text { water demand }\end{array}$ & $\begin{array}{l}\text { The current total population of Iran is about } 79 \text { million, of which about } 70 \text { percent are living } \\
\text { in urban areas. But in the future, it is expected that } 80 \text { percent of the total population may live } \\
\text { in urban areas and especially in big cities like Tehran, Mashhad, and Isfahan. Iran's population has } \\
\text { more than doubled since the } 1979 \text { revolution and has grown eightfold since } 1900 \text {. At present, seven cities } \\
\text { in Iran have populations of over one million. The current water consumption per capita in Tehran, } \\
\text { which is the most populated urban city in Iran, is about } 378 \text { liters per day (L/d). If the current water } \\
\text { consumption trend continues, without water conservation plan, the total water consumption in } 2026 \text { is } \\
\text { projected to be } 1290 \text { million cubic meters per year }(\mathrm{MCM} / \mathrm{yr})[6] \text {. With this projection, even if all } \\
\text { current available water resources were utilized to their fullest capacities, the city of Tehran would } \\
\text { still be faced with a water shortage of more than } 100 \mathrm{MCM} / \mathrm{yr} \text { in drought years. }\end{array}$ \\
\hline
\end{tabular}


Table 2. Summary review of factors affecting water shortage problem in Iran (continued).

\begin{tabular}{ll}
$\begin{array}{c}\text { Contributing } \\
\text { factor }\end{array}$ & \multicolumn{1}{c}{ Description } \\
\hline & The agricultural sector in Iran consumes the largest fraction of total available water $(83.5 \mathrm{bcm}$ or \\
& 92.8 percent). Of this amount, about 50 percent is from surface water resources and another 50 \\
& percent is from groundwater aquifers. Groundwater extraction (through wells, qanats and springs) \\
& varies from less than $20 \mathrm{bcm} /$ year in the early 1970 s to over $74 \mathrm{bcm} /$ year at the beginning of the \\
agricultural & present millennium. The number of wells during this period increased fivefold, from just over 9,000 \\
irrigation & to almost $45,000$. Groundwater depletion is estimated at $4.8 \mathrm{bcm} /$ year. Most of the water \\
& exploitation happens in the central basins where less surface water is available. It is estimated \\
& that the water levels in Iranian aquifers have declined by an average of nearly half a meter every \\
& year over the last 15 years. Total surface water and groundwater withdrawal represents almost 70 \\
& percent of the total actual renewable water resources.
\end{tabular}

There might be multiple water mismanagement issues, some of which are briefly described below.

The first mismanagement issue may be related to the construction of dams for water management by focusing the storage capacity of surface water. This approach is only helpful with adequate annual precipitation and when there is plenty of available surface water, which is lacking in Iran. For example, in 2006, 94 large storage dams with a total capacity of $31.6 \mathrm{bcm}$ were operating and 85 large dams with a capacity of $10 \mathrm{bcm}$ were under construction. The total storage capacity of many dams in Iran amounts to 68 billion cubic meters, whereas the water potential of the Iran's rivers totals 46 billion cubic meters per annum [7].

The second mismanagement issue is related to the government's inability to control the population growth based on the projected water availability or developing a plan to increase the water supply to meet the future demand. Water availability per capita in the pre-Islamic revolution era was about $4,500 \mathrm{~m}^{3}$. But, in 2005 this figure was less than $1,750 \mathrm{~m}^{3} /$ capita and is estimated to be $1,300 \mathrm{~m}^{3}$ /capita by 2020 [8]. Generally, a country will experience water stress when freshwater supplies fall below $1,700 \mathrm{~m}^{3}$ per person per year [9]. Clearly, Iran is beginning to encounter the critical water stress level.

The third management issue is related to the inefficient water consumption in agriculture sector

Water mismanagement that has been discussed above. Because the agricultural sector is a major water user in Iran, the governmental authorities should work together and create a policy to reform the irrigation system and crop production to conserve water. This lack of appropriate policy may be due to a conflict of interest among multiple governmental agencies toward water usage in Iran as indicated below.

The forth management issue is related to the fact that the water resources are managed by different governmental entities with conflicting interests towards water management and usage. According to the national law, all water bodies (rivers, lakes, etc.) are public property and the government is responsible for their management. The first water law after the revolution was approved in 1982 and according to this water legislation, three ministries are directly in charge of water resources management and development [10]. The conflict of interest among multiple agencies found to be problematic for Iran's water management. The role and responsibility of multiple governmental agencies must be reformed and adopt a new integrated and sustainable water management plan. Perhaps, because of the seriousness of water shortage problem and to secure the future availability of water in Iran, it might be even logical to create a single new agency that could deal with all of Iran's water related issues. 


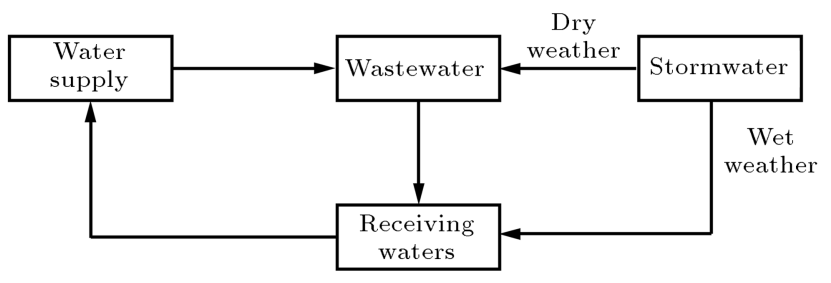

(a)

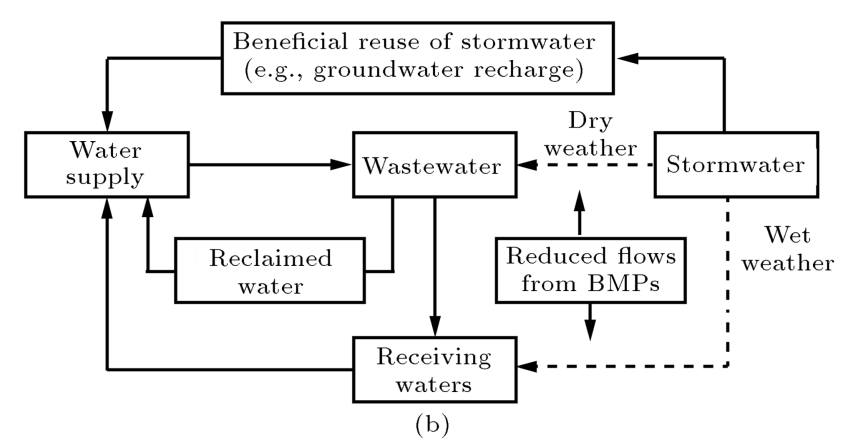

Figure 1. Water resources management schemes: (a) Traditional non-integrated; and (b) traditional integrated (adapted from U.S. EPA [11]).

\subsection{Strategies for developing an integrated water management Plan}

Management strategies and alternative resources typically considered in an integrated water management plan, include:

- Water conservation;

- Wastewater reuse;

- Greywater reuse;

- Stormwater reuse through BMPs;

- Rainwater harvesting;

- Enhanced groundwater recharge;

- Increased surface water detention;

- Dry weather urban runoff treatment;

- Dual plumbing for potable and non-potable uses;

- Separate distribution systems for fire protection;

- Multi-purpose infrastructure;

- Use of the right water quality for intended use;

- Green roofs;

- Low Impact Development (LID).

Under the umbrella of an integrated plan, the development and management of facilities and policies for water, wastewater, stormwater, reclaimed water, and energy can be evaluated concurrently. The integrated approach brings together resources that share a common environment as well as bringing together the people who manage or are affected by the resources and their infrastructure.
Unfortunately, most of the strategic approaches, cited above, are not practiced in many parts of the world. It is clear that Iran will have a better chance of solving its current water shortage problem by adapting an integrated water management approach. A new integrated and sustainable approach must be adapted to move Iran from the current situation to a nation free of water shortage problems. Some key strategic approaches that can be taken to deal with the current water shortage problems and/or to increase additional water supply may include:

1. Implement desalination plants to southern population centers;

2. Implement major public outreach programs for water conservation and efficient use of water;

3. Invest more in wastewater collection and wastewater treatment systems;

4. Implement water reuse throughout the country and use as much treated wastewater as possible for agricultural purposes so that surface and groundwater freshwater supplies can be allocated for residential and industrial use;

5. Restructure water use in the agricultural sector; both in terms of volume consumption and increasing the efficiency;

6. Manage reuse water to address environmental sustainability without compromising the need for other developments;

7. Develop a series of water quality and environmental legislations and establish water quality standards for various uses;

8. Develop monitoring guidelines and revise the existing documentations for safe use of reclaimed water for various applications based on the new water quality standards established above;

9. Establish a new water management agency to deal with all aspects of water related issues in Iran.

\subsection{Rational for adapting water reuse program in Iran}

As part of the new integrated and sustainable water management program, major emphasis should be given to all untapped sources of water including: intercepted rainwater (e.g., rooftop rainwater harvesting), surface stormwater runoff, onsite and decentralized greywater, and reclaimed municipal wastewater effluent. Although, none of the above reuse options are practiced systematically in Iran at present time, reuse of treated municipal wastewater effluent (including greywater) and stormwater for beneficial purposes may play an important role in augmenting the existing water portfolio. The need for augmenting the existing water supply will be more apparent as the population increases. At 
present, the population of Iran is about 79 million and it is estimated that the population will increase to about 90 million by 2050 . Nearly 80 percent of the total Iranian population lives in urban areas, especially in big cities like Tehran, Isfahan, Mashhad, and Tabriz. Hence, water reuse could potentially alleviate some of the water shortage problem in Iran.

Up to now, the water reuse has not been considered fully in the water resources management plan in Iran. The majority of the non-integrated and unofficial reuse of reclaimed water is related to non-potable reuse (see Table 3). Technical and economic feasibility of wastewater reuse for landscape irrigation for city of Tehran was evaluated in the past [13]. Recently, two books have been published on water reuse in which some elements of water reuse applications have been discussed and mostly focused on non-potable reuse $[14,15]$. The only potable reuse of reclaimed water is through unplanned reuse. The lack of integrated water reuse in Iran may partially be due to limited centralized sewage collection and wastewater treatment infrastructures. For instance, the majority of the wastewater treatment systems has been constructed and operated after 1990's. In 2000, there were only 37 Wastewater Treatment Plants (WWTP's) with a total capacity of about $700,000 \mathrm{~m}^{3} / \mathrm{d}$, treating the wastewater produced by a population of 2.3 million [16]. By the end of 2010 , the number of wastewater treatment plants increased to 129 serving close to 13 million inhabitants [16].

These combined wastewater treatment plants generated over 2.4 million $\mathrm{m}^{3} / \mathrm{d}$ of treated effluent.

Table 3. Description of methods employed for reuse application in Iran*.

\begin{tabular}{|c|c|}
\hline Reuse application & Description \\
\hline $\begin{array}{l}\text { Indirect (de facto) } \\
\text { potable reuse }\end{array}$ & $\begin{array}{l}\text { Many cities in Iran are still lacking systematic sewage collection and wastewater treatment } \\
\text { system. Wastewaters from households enter into seepage pits, infiltrates through layers of the } \\
\text { ground ultimately reaching and recharging underground aquifers. } \\
\text { The average distance between the water table and the bottom of these seepage pits should be } \\
\text { above } 20 \mathrm{~m} \text {. Because of rapid population growth and lack of other available surface water, } \\
\text { some urban communities draw their drinking water supply from these underground strata, } \\
\text { which act as an indirect potable reuse. }\end{array}$ \\
\hline $\begin{array}{l}\text { Indirect groundwater } \\
\text { recharge for } \\
\text { non-potable reuse }\end{array}$ & $\begin{array}{l}\text { This reuse method is practiced around the major city limits where underground aquifers } \\
\text { are recharged with the seepage pits, and WWTP effluent that recharge a brackish groundwater } \\
\text { aquifer through streambeds and channels and eventually are used downstream through } \\
\text { springs and qanats by farmers to irrigate their fields and others for various non-potable } \\
\text { purposes. }\end{array}$ \\
\hline $\begin{array}{l}\text { Direct non-potable } \\
\text { reuse }\end{array}$ & $\begin{array}{l}\text { Treated or partially treated wastewater is used directly for irrigation without being mixed } \\
\text { or diluted with groundwater or surface water. This is commonly practiced and was planned } \\
\text { as part of reuse method for most treatment plants operation. In some cases the treated } \\
\text { effluent water has been transported from the treatment plant to the farmers to augment } \\
\text { the water supply and reduce the pressure associated with limited drinking water supply (i.e. } \\
\text { city of Mashhad during the recent drought). Unfortunately, the quality of water used by this } \\
\text { method is not fully regulated. In addition, no sufficient data is available to determine the } \\
\text { amount of water used under this method and what fraction is applied for the production of } \\
\text { crop, vegetables or fruits that are consumed by cooking or eaten as uncooked. }\end{array}$ \\
\hline $\begin{array}{c}\text { Indirect non-potable } \\
\text { reuse }\end{array}$ & $\begin{array}{l}\text { Under this method, untreated wastewater is diluted and mixed with the stormwater or small } \\
\text { streams or tributaries of larger water bodies and then used for irrigation. The diluted water } \\
\text { solely goes through natural physical and biological treatment and is commonly used for } \\
\text { unrestricted irrigation in downstream of urban cities where wastewater treatment facilities } \\
\text { are inadequate. }\end{array}$ \\
\hline
\end{tabular}

\footnotetext{
* Source: Partially adapted from Tajrishy et al. [16]
} 
Wastewater is primarily produced from the municipal sector and is generally treated through secondary biological treatment with no further treatment due to cost consideration. Out of 129 treatment plants, 51 are activated sludge, 33 aerated ponds, 41 facultative lagoons and 2 sequential batch reactor, 1 wetland, and 1 trickling filters. Currently, plans are under consideration for the reuse of the effluent produced from a number of secondary treatment plants, with the majority being used for non-potable agricultural reuse (see Table 4).

As of 2010, approximately $33 \%$ of wastewater generated in Iran was collected, $23 \%$ of the collected wastewater was treated, and only about $9 \%$ of treated effluent was reused. The number of wastewater collection systems and wastewater treatment plants is projected to grow, with the ultimate, the goal of providing wastewater collection and treatment systems for $75 \%$ of the entire population by 2020 . Therefore, there is a tremendous opportunity for water reuse in Iran as that will add more water supplies to the current water portfolio and provide relief to the existing water scarcity. The feasibility of water reuse in urban city of Tehran has been confirmed by a recent modeling study performed by Tajrishy et al. [16]. Based on the modeling results improving the quality of WWTP effluent for reuse would result in reduced freshwater and groundwater usage. As fresh water and groundwater usage decreases, the growing water demand will be met and the falling groundwater level in Tehran and surrounding areas will stabilize.

In the future, the majority of existing treatment plants could be upgraded to produce a higher quality effluent. Any future proposed wastewater treatment plants could also be designed, constructed, and operated to produce higher quality water for wide ranges of application including non-potable and potable reuse.

\section{Type of potable reuse}

Along with surface water and groundwater, potable reuse involves the use of a community's wastewater as a potable water source in the water portfolio. The principal types of potable reuse, practiced currently in the United States and elsewhere in the world, include planned and unplanned potable reuse. Planned potable reuse can include: (1) Indirect Potable Reuse $(I P R)$ in which treated wastewater is introduced into an environmental buffer (e.g., a groundwater aquifer or surface water reservoir, lake, or river) before the blended water is introduced into a water supply system; and (2) Direct Potable Reuse (DPR) in which highly treated wastewater is introduced at various locations into an existing water supply system. The planned IPR and DPR are described in Sections 3.1 and 3.2, respectively.

Unplanned potable reuse is often identified as de facto potable reuse. Unplanned potable reuse occurs when downstream surface waters subject to upstream wastewater discharges are used as a source of drinking water. Unplanned potable reuse is a common occurrence in a number of drinking water supplies derived from surface water sources, principally rivers [17], and has been understood for at least 100 years, including how to address its issues and challenges [18]; however, the practice is not recognized officially [11]. As noted in Section 2.4, the majority of potable reuse of reclaimed water in Iran is unplanned. Unplanned potable reuse is not addressed in this paper.

\subsection{Planned Indirect Potable Reuse (IPR)}

Two graphical representations of IPR are shown in Figure 2. As shown, in an IPR process, Advanced Treated Water (ATW) or tertiary effluent is introduced into an environmental buffer before being withdrawn for potable purposes. The purpose of the environmental buffer is to provide storage, transport, and, in some cases, an additional barrier for the protection of public health; however, the environmental storage of highly treated water, if not stabilized or mixed with other water, can also add contaminants and degrade the water (e.g., dissolution of metals from the groundwater

Table 4. Summary of discharge and reuse option planned or practiced by the number of wastewater treatment plants as of $2010^{*}$.

\begin{tabular}{lc}
\multicolumn{1}{c}{ Discharged or reuse plan option } & $\begin{array}{c}\text { Reuse application } \\
\text { practiced or planned by the } \\
\text { number of treatment plants }\end{array}$ \\
\hline Discharged to rivers for indirect (de facto) potable reuse & 47 \\
Discharged to river for indirect irrigation use & 20 \\
Direct agricultural reuse only & 63 \\
Indirect groundwater recharge for potable and non-potable reuse & 5 \\
\hline Note: 107 additional wastewater treatment plants with total design capacity of 1177 million $\mathrm{m}^{3}$ are in design process that can \\
be used for water reuse application \\
* Source: Tajrishy et al. [16].
\end{tabular}




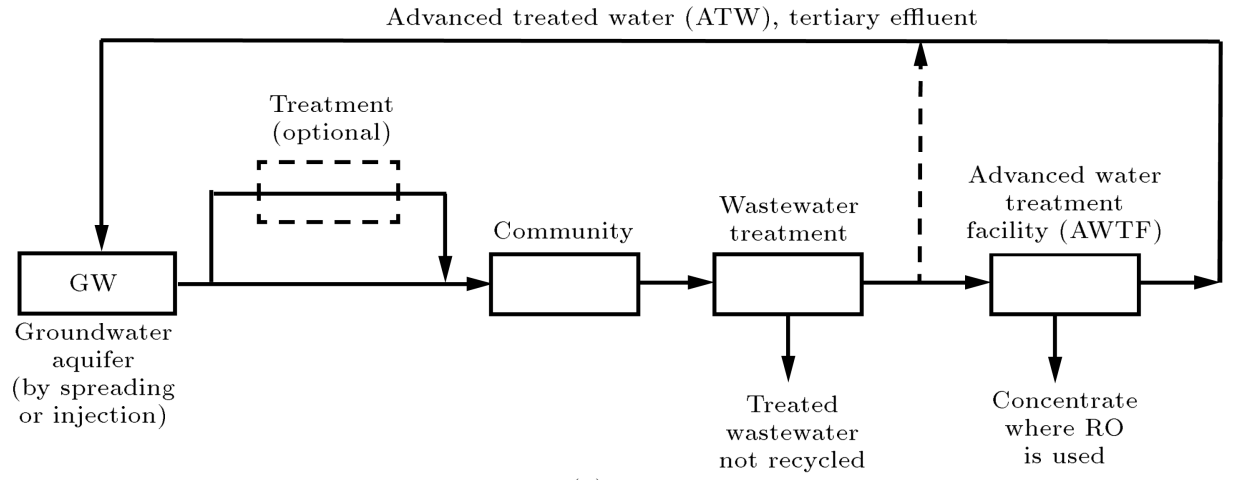

(a)

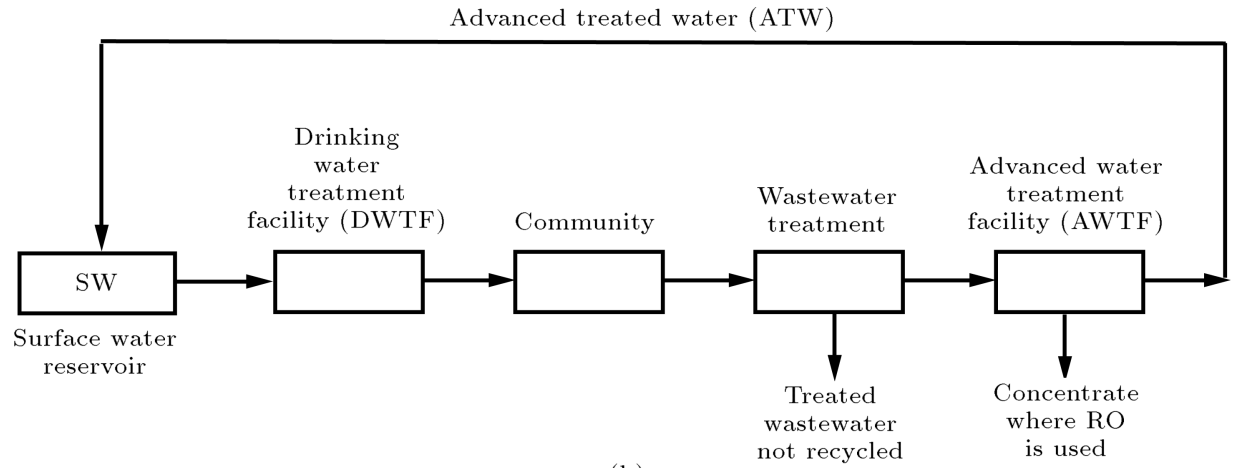

(b)

Figure 2. Flow diagrams for IPR with (a) a groundwater aquifer as an environmental buffer, and (b) a surface water reservoir as an environmental buffer (source: Tchobanoglous et al. [3]).

aquifer or microbial and other contaminants in surface impoundments).

\subsubsection{IPR with groundwater $(G W)$ as an environmental buffer}

In Figure 2(a), the environmental buffer is a groundwater aquifer. ATW can be applied by spreading or direct injection, whereas tertiary effluent is applied by spreading to take advantage of soil aquifer treatment. Planned IPR through the recharge of groundwater aquifers has been practiced in Orange County, California, since 1962 [19].

\subsubsection{IPR with Surface Water $(S W)$ as an environmental buffer}

In Figure 2(b), a surface water reservoir or other water body serves as the environmental buffer. Planned augmentation of a surface water source with treated wastewater has been practiced in Fairfax County, VA, since 1978 (UOSA, no date). It is also important to note that when the volume of the reservoir or other water body does not meet required dilution and storage requirements, the proposed IPR project [see Figure 2(b)] becomes a DPR project [see Figure 2(a)].

\subsection{Planned direct potable reuse}

There are two forms of DPR in use today: One involves ATW, and the other involves Finished Wa- ter (FW). Graphical representations of both DPR forms are illustrated in Figure 3. In Figure 3(a), ATW is introduced with or without the use of an Engineered Storage Buffer (ESB) into the raw water supply immediately upstream of a Drinking Water Treatment Facility (DWTF). In Figure 3(b), finished water is directly introduced - with or without the use of an ESB - into a drinking water supply distribution system, either downstream of a DWTF or within the distribution system. When introduced upstream of a DWTF [see Figure 3(a)], ATW becomes essentially another source of raw potable water. ATW typically meets all drinking water standards and regulations; however, it cannot be introduced directly into the distribution system as finished water if it was not produced in a facility permitted as a DWTF. When ATW is introduced upstream of a DWTF, the DWTF serves as an additional treatment barrier to provide an added factor of safety.

\subsubsection{Treatment train with an engineered storage buffer}

An Engineered Storage Buffer (ESB), shown as a dashed box in Figure 3(a), may be used before the ATW is introduced upstream of a DWTF; if used, the purpose of the ESB is to provide a water storage containment facility of sufficient volumetric capacity to retain ATW for a specified time period [20]. 


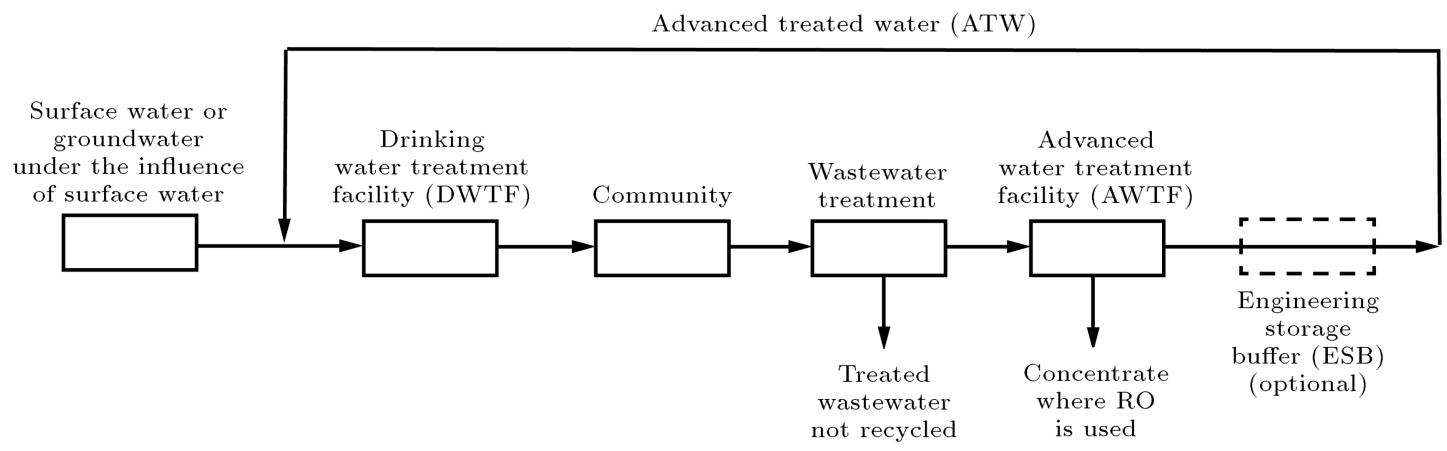

(a)

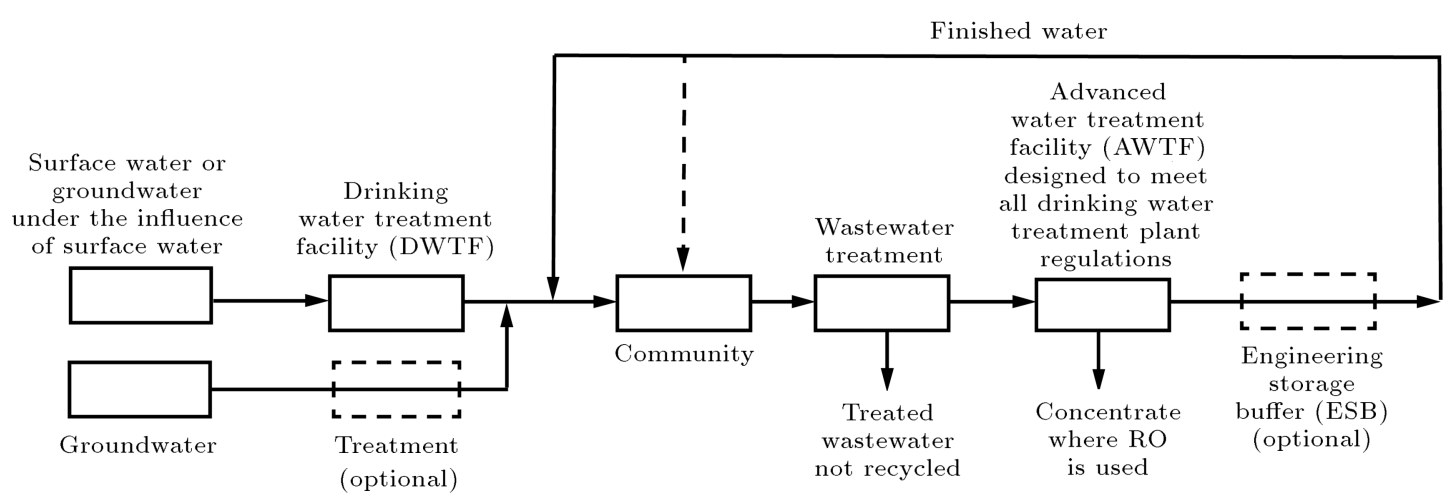

(b)

Figure 3. Flow diagrams for DPR: (a) With ATW introduced upstream of a DWTF; and (b) finished water introduced into the drinking water supply distribution system downstream of a DWTF (source: Tchobanoglous et al. [3]).

To ensure that the quality of the ATW meets all applicable water quality-related public health standards or quality measures prior to being introduced into a DWTF, the amount of time required to hold the ATW in the ESB should be sufficient to allow for flow continuity and the measurement and reporting of specific constituents. This definition does not mean that all regulatory standards must be monitored in the ESB prior to the release of the ATW; rather, it provides an opportunity to monitor for select key water quality performance parameters. The use of an ESB is critical when the Advanced Water Treatment Facility (AWTF) does not have (1) redundancy or critical treatment processes that are monitored routinely (e.g., daily), and (2) online metering that can be used to monitor treatment performance accurately.

\subsubsection{Treatment train without an engineered storage buffer}

When an ESB is not used, as represented by the dashed box in Figure 3(a), the AWTF should have the following: (1) redundant treatment to allow for the continuous production (or retreatment or discharge) of ATW if one of the major treatment processes is out of specification; and (2) effective monitoring to demonstrate sufficient treatment protective of public health.

\subsubsection{Direct introduction of finished water into the drinking water supply distribution system}

Finished water, produced in an AWTF that is also permitted as a DWTF, could theoretically be introduced directly into the drinking water distribution system, as shown in Figure 3(b). The drinking water in the distribution system can be (1) treated surface water, or (2) treated or untreated groundwater, which may or may not be disinfected. At this time, several important issues about this practice are unresolved and need to be addressed. In the future, as monitoring technologies become more sensitive for the measurement of critical Constituents Of Concern (COCs), it is likely that the DWTF will be bypassed, assuming all public health and monitoring requirements are being met and the AWTF is also permitted as a DWTF. Because of the many unknowns associated with the management of finished water, this form of DPR will require additional studies to demonstrate the feasibility and safety of the practice; therefore, it is not recommended in Iran.

\subsection{Energy and cost considerations}

When determining whether to proceed with a PR program, it is useful to compare the issues associated with developing and implementing alternative water sources and measures to those for PR. With no ad- 
Table 5. Comparative issues with alternative sources of water supply to potable reuse.

\begin{tabular}{|c|c|}
\hline $\begin{array}{c}\text { Alternative } \\
\text { water supply }\end{array}$ & Comparative issues \\
\hline $\begin{array}{l}\text { Imported } \\
\text { Water }\end{array}$ & $\begin{array}{l}\text { - New sources of imported water are difficult, if not impossible, to develop; particularly considering } \\
\text { the long-terms issues related to safety, security and reliability. } \\
\text { - Withdrawing water from inland areas, transporting it to population centers, treating and using it. } \\
\text { once, and discharging it to coastal waters is, in the long term, less sustainable than other options. } \\
\text { - Imported water sources: (1) are subject to natural and institutional disruptions and limitations, } \\
\text { resulting in potentially large inter annual variability; (2) can be of variable quality (e.g., high salt } \\
\text { load); (3) often require significant amounts of energy for transport; (4) can impose significant } \\
\text { adverse environmental consequences when local water is extracted; (5) reduce potential } \\
\text { environmental impacts of wastewater discharges to surface waters; and (6) are relatively } \\
\text { expensive, the cost of which will continue to escalate in the future. } \\
\text { - Imported water is also subject to natural and societal forces that are difficult to control, including: } \\
\text { (1) increased demands from population growth; (2) drought; (3) changes in snowpack, rainfall, or } \\
\text { other natural sources of replenishment; (4) seismic events; and (5) future environmental regulations, } \\
\text { water rights determinations, and associated legal challenges. } \\
\text { - In many locations, imported water increases local salt loading. } \\
\text { - Extensive treatment may be required for low-quality imported water sources. }\end{array}$ \\
\hline Desalination & $\begin{array}{l}\text { - Desalination of water from Persian Gulf and Caspian Sea is a technically feasible option that can } \\
\text { provide a high-quality, potable supply after blending or chemical addition, but with a number of } \\
\text { drawbacks, including: (1) potential environmental impacts associated with ocean feedwater intakes, } \\
\text { brine disposal and discharges, and construction of facilities at sensitive shoreline or near-shore } \\
\text { locations; (2) relatively high energy demands for treatment and especially for pumping to } \\
\text { populated areas; (3) large carbon footprint; (4) feedwater quality that is vulnerable to red tides } \\
\text { and other ocean water quality challenges; (5) coastal facilities that may be vulnerable to sea level } \\
\text { rise and storm surges; and (6) security threats based catastrophic failure. } \\
\text { - Desalination of water from Caspian Sea or inland brackish water is less costly than the Persian Gulf } \\
\text { water desalination because of much lower salt content, but has significant brine management } \\
\text { challenges. } \\
\text { - Ocean desalination is more expensive than potable reuse, often by a factor of } 2: 1 \text { per gallon. } \\
\text { - When desalinated source water is recycled, it increases the amount of water available for local } \\
\text { beneficial use. }\end{array}$ \\
\hline
\end{tabular}

ditional water availability, two of the most immediate water supply alternatives in Iran may include desalination and importing water from neighboring countries. Comparative issues with respect to imported surface waters and desalination is summarized in Table 5. The Energy and carbon footprint consideration and cost consideration is presented in Sections 3.3.1 and 3.3.2, respectively.

\subsubsection{Energy and carbon footprint}

The energy required and carbon footprint of AWTF compared with imported water and desalination projects are reported in Table 6 . The data presented in Table 6 are generated in the United States and, hence, should only be viewed qualitatively rather than quantitatively. As shown, the potable reuse option is less energy intensive and has a lower carbon footprint as compared to the other two alternatives.

\subsubsection{Cost}

Comparative costs for treatment, residual management, concentrate management, and conveyance facilities for an AWTF with other alternative sources are presented in Table 7. Again, the data shown in Table 7 were collected from the United States and should be viewed qualitatively rather than quantitatively. As shown, the cost range of producing clean potable reuse water from AWTF with/without RO is generally 
Table 6. Comparative energy requirements and carbon footprint for different alternative sources of surface water*.

\begin{tabular}{|c|c|c|c|}
\hline \multirow[t]{2}{*}{ Technology/water source } & \multicolumn{2}{|c|}{ Energy required } & \multirow{2}{*}{$\begin{array}{l}\text { Carbon footprint } \\
\qquad\left(\mathrm{kg} \mathrm{CO} \mathrm{CO}_{2} / \mathrm{m}^{3}\right)\end{array}$} \\
\hline & $\begin{array}{c}\text { Range } \\
\left(\mathbf{k W h} / \mathbf{m}^{3}\right)\end{array}$ & $\begin{array}{c}\text { Typical } \\
\left(\mathbf{k} \mathbf{W h} / \mathbf{m}^{3}\right)\end{array}$ & \\
\hline AWTF & $0.86-1.06$ & 0.25 & 0.48 \\
\hline Backwash water desalination & $0.82-1.64$ & 0.41 & 0.77 \\
\hline Ocean desalination & $2.51-3.89$ & 0.84 & 1.58 \\
\hline Interbasin transfer of water, California, USA & $2.09-2.62$ & 0.64 & 1.21 \\
\hline Interbasin transfer of water, Colorado River, USA & $1.62-1.95$ & 0.43 & 0.81 \\
\hline
\end{tabular}

* Source: Tchobanoglous et al. [3].

Table 7. Comparative unit costs of advanced treated water with other water supply options*.

\begin{tabular}{lcccc}
\hline Water supply option & \multicolumn{3}{c}{ Cost $\left(\$ / \mathbf{m}^{3}\right)$} \\
\cline { 2 - 5 } & Treatment & $\begin{array}{c}\text { Residuals } \\
\text { management }\end{array}$ & $\begin{array}{c}\text { Concentrate } \\
\text { management }\end{array}$ & $\begin{array}{c}\text { Conveyance and } \\
\text { blending facilities }\end{array}$ \\
\hline AWTF with RO & $0.55-0.72$ & $0.008-0.04$ & $0.06-0.63$ & $0.08-0.81$ \\
AWTF without RO & $0.32-0.57$ & $0.008-0.04$ & Not applicable & $0.08-0.81$ \\
Brackish groundwater desalination (inland) & $0.33-0.67$ & $0.005-0.02$ & $0.06-0.63$ & $0.08-0.81$ \\
Seawater desalination & $1.58-2.83$ & $0.02-0.08$ & $0.06-0.16$ & $0.32-2.43$ \\
Retail cost of treated imported surface water & \multicolumn{2}{c}{$0.32-1.05$} & Not applicable & $0.08-0.49$ \\
\hline
\end{tabular}

*Source: Tchobanoglous et al. [3].

lower than the cost of the other alternatives. During the drought years, cost considerations are even more important.

\section{Examples of successful operation of three potable reuse projects}

Three potable reuse projects (both indirect and direct potable) are presented and discussed in this section. The projects considered include: (1) Orange County Water District (OCWD) Ground Water Replenishment (GWR) indirect potable reuse, (2) Singapore NEWater indirect potable reuse, and (3) Windhoek, Namibia direct potable reuse. Although, numerous other potable reuse projects have been operated throughout the world, these projects were selected for several reasons, most notably: (a) production of consistent high quality potable water, (b) availability of long-term operation and monitoring data, and (c) access to public for touring and operational observation. For consistency, each project is presented based on their background information, treatment train processes employed, and lessons learned.

\section{1. $O C W D G W R I P R$ project}

For decades, semi-arid Orange County, California, has depended on imported water from Northern California and the Colorado River for much of its drinking water supply. However, with multi-year droughts and environmental constraints, imported water is becoming more expensive and less available. Population studies indicate that California could increase an additional 15 million people by 2020; Southern California alone could grow by 7 million and Orange County by 300,000. In the 1990s, the Orange County Water District (OCWD) and Orange County Sanitation District (OCSD) joined efforts to provide a reliable water supply by developing a water purification program called the Groundwater Replenishment System (GWRS), which came on-line in January 2008. Prior to the GWRS, OCWD operated Water Factory 21 (WF- 21), a first-of-its-kind water treatment facility that produced $960 \mathrm{~L} / \mathrm{s}$ (15 mgd) for a seawater intrusion barrier, from 1976 through 2004. Currently, GWRS is the largest water reclamation facility of its kind in the world with capacity of $4381 \mathrm{~L} / \mathrm{s}$ (100 mgd) employing the latest advanced treatment technologies. The GWRS has been studied exhaustively, determined to produce highly purified water, and meeting all applicable numeric drinking water standards [21].

Using up to two-thirds less energy than it would take to import water from Northern California, and three times less energy than ocean desalination, the GWRS currently produces enough water for nearly 600,000 residents, while saving enough energy to power 21,000 homes each year. Additional benefits include eliminating the need for another ocean outfall and increasing "water diversity" in an arid region. The 
OCWD's groundwater replenishment system (GWRS) for the production of potable water is in operation since 2008.

\subsubsection{Treatment train processes employed}

The source of water for GWRS is undisinfected secondary effluent from the Orange County Sanitation District (OCSD). The Advanced Water Treatment Facility (AWTF) process flow diagram, shown on Figure 4, includes the following unit processes: microfiltration, cartridge filtration, reverse osmosis, advanced oxidation (UV photolysis and hydrogen peroxide), carbon dioxide stripping, and lime addition. The product water is discharged to existing spreading basins and seawater barrier injection wells. Purified water and other sources of dilution water introduced to the spreading basins mix with water from other sources and percolates into the groundwater aquifers, where it eventually becomes part of Orange County's drinking water supply. Water pumped to the injection wells serves as a barrier to salt water intrusion and also becomes part of the drinking water supply.

The only difference between the OCWD system and a conceptual DPR system (see Section 4.3 below) is that recycled water from the OCWD system is introduced into an environmental buffer for a minimum of six months, where it is presumed that it may receive some additional treatment and lose its identity as recycled water. However, because of the high level of purification, further treatment in the environment is not required. Thus, the OCWD system could be used for DPR, by an introduction into the head works of a water treatment facility [(see Figure 3(a)]. The product water from the GWRS meets and/or exceeds, all of the California Division of Drinking Water requirements for potable water and the Santa Ana Regional Water Quality Control Board requirements for IPR.

\subsubsection{Lessons learned}

To increase the public acceptance of IPR, an aggressive outreach program was established to educate and secure support from local, state and federal policymakers, business and civic leaders, health experts, environmental advocates and academia. Because of the negative and misinformed public perception of purifying wastewater to drinking water, the agencies decided that the "clean water" agency should be out front to manage day-to-day management of the outreach campaign. To brand the safety, purity and high quality of water, OCWD staff led outreach and interfaced with consumer media, while OCSD staff served as advisors on outreach decisions and helped manage trade media relations. The team made more than 1,200 presentations from 1999 to 2007 , secured thousands of media impressions, and garnered more than 600 letters of support including those from all 21 city councils, the district's senators and congressional representatives, local state assembly members, state senators, the governor, and the Orange County Board of Supervisors. The OCWD GWR IPR project also had the support of the regulators such as the Department of Water Resources, California Department of Public Health (CDPH), Division of Drinking Water (DDW) of the State Water Resources Control Board, and the Santa Ana Regional Water Quality Control Board (RWQCB).

OCWD and OCSD successfully partnered to build a potentially controversial water project that garnered overwhelming public support and overcame a "toilet-
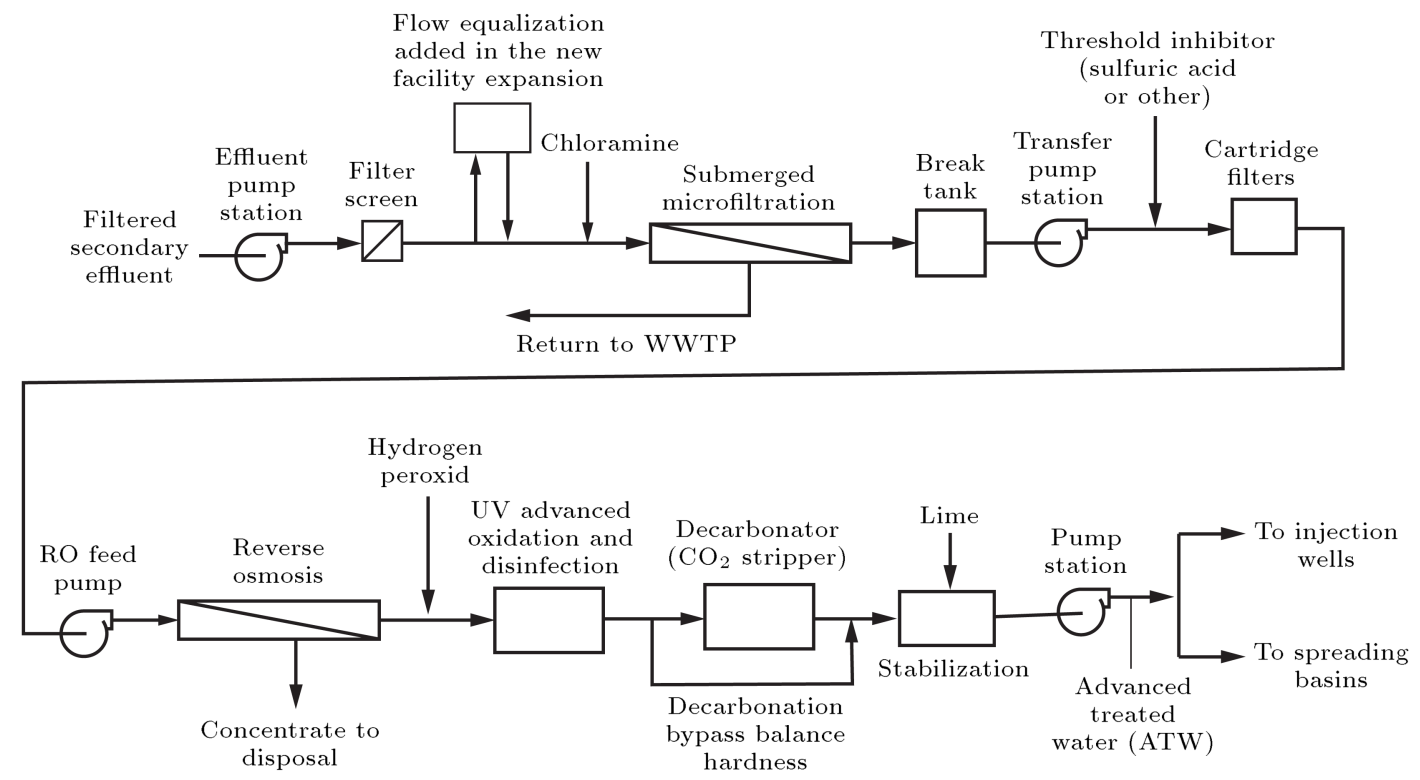

Figure 4. Schematic flow diagram for the advanced reclaimed water treatment facility at the Orange County Water District, Fountain Valley, CA (adapted from Tchobanoglous et al. [20]). 
to-tap" misperception. The GWRS has revolutionized how consumers look at wastewater, as another resource, they should take care of and reuse. The partnership between OCWD and OCSD has become an international model for water recycling recognized globally with numerous awards, including the prestigious Stockholm 2008 Industry Water Award, Säid Khoury Award for Engineering Construction Excellence, and the American Society of Civil Engineers Outstanding Civil Engineering Achievement. Municipalities across California, the United States, and Australia are planning similar projects. In fact, the Singapore NEWater project, described below, was modeled after the OCWD GWRS.

\subsection{Singapore NEWater project}

Singapore, being a small island city-state of about 700 square $\mathrm{km}$ and a population of 5 million, has no natural aquifers or groundwater, and relies on rainfall from catchments and raw water imported from the neighboring Johor state in Malaysia. These sole water sources, however, are subject to the vagaries of nature, leaving Singapore vulnerable to water shortages. To achieve a sustainable and robust water supply to meet increasing water demands, Singapore has diversified its water sources, termed the 4 National Taps, namely: (1) imported water from Johor, (2) Malaysia local catchment water, (3) NEWater, and (4) desalinated water.

NEWater is high-grade reclaimed water that meets drinking water standards and is the key component of achieving water sustainability in Singapore. Currently, NEWater is supplied from five NEWater factories in Singapore, with total capacities of $554,600 \mathrm{~m}^{3} / \mathrm{d}$ (122 $\left.\mathrm{mgd}\right)$. The total capacity of the NEWater factories is projected to reach some $873,000 \mathrm{~m}^{3} / \mathrm{d}$ (192 $\mathrm{mgd}$ ) by 2020. A large portion of NEWater is used for computer chip fabrication and electronics industries, where the water quality requirement is more stringent than that for drinking water. NEWater is also used in commercial and institutional complexes for air-conditioning cooling purposes. These applications free up potable water for domestic use. In addition, NEWater supplements Singapore's potable water supply via planned Indirect Potable Reuse (IPR).
Planned IPR involves blending NEWater with raw reservoir water, and then subjecting the blended water to the same conventional water treatment process as raw reservoir water to produce potable water. In February 2003, the Public Utilities Board (PUB), the national water agency of Singapore, began pumping $7570 \mathrm{~m}^{3} / \mathrm{d}$ ( $2 \mathrm{mgd}$ ) of NEWater into reservoirs for IPR [(see Figure 2(b)]. It was increased progressively to about 2.5 percent of total potable water consumption in 2011 .

\subsubsection{Treatment train processes employed}

The NEWater treatment process flow diagram is shown in Figure 5. NEWater is produced from treated used water (wastewater) that is purified further using advanced membrane technologies and ultraviolet (UV) disinfection, making the water ultra-clean and safe to drink. The United States Environmental Protection Agency (U.S. EPA) Primary and Secondary Drinking Water Standards (Safe Drinking Water Act) and WHO Drinking Water Quality Guidelines are the benchmarks set for NEWater quality.

To ensure that NEWater is of a quality safe for IPR, the multiple barrier approach is utilized incorporating enforcement, plant design, plant operation, plant maintenance and water quality monitoring. This approach is audited bi-annually by an External Audit Panel comprised of 2 experts from the local tertiary institution and 5 overseas experts of international standing, and also by an Internal Audit Panel. The multi safety barrier approach starts from the source and extends to taps in households [17].

The approach is further enhanced by a Sampling And Monitoring Program (SAMP), which covers the entire delivery chain of NEWater to determine the suitability of NEWater for IPR and non-potable reuse; and a strict operating philosophy. The SAMP is comprised of a comprehensive physical, chemical and microbiological sampling and analysis of water samples. To-date, 300 parameters are monitored including emerging contaminants of concern listed in the U.S. EPA Priority List of Contaminants. The operating philosophy adopted in NEWater factories is based on operating with reference to the baseline

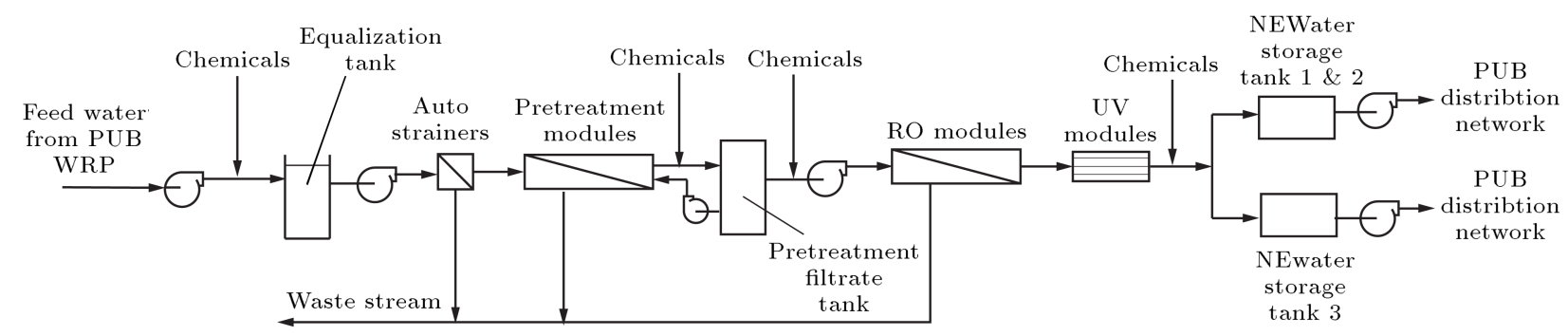

Figure 5. Flow diagram of Singapore NEWater purification system (source: www.keppelseghers.com/en/download.ashx?id=8666). 
performance of the plants. Such mode of operation is to maintain the water quality of the treated permeate close to the expected baseline readings, which are well within the WHO Drinking Water Guidelines and U.S. EPA Drinking Water Standards, during the daily operations. Water analysis through grab sampling and on-line monitoring has shown consistently that NEWater quality is of drinking water standards, even as the membrane ages over the expected life span of 5 years. Water quality parameters currently (as of June 2015) monitored showed that the NEWater consistently exceeds the requirements set by WHO guidelines and generally is cleaner than the other Singapore's water sources (PUB's Water Quality Office:

http://www.pub.gov.sg/general/watersupply/Pages /DrinkingWQReport.aspx)

\subsubsection{Lessons learned}

An important part of the NEWater success story is its high public acceptance. This acceptance was achieved through a long and extensive public education program done in various phrases. Before NEWater's launch, extensive briefings were held for critical groups, which comprised of community leaders, business communities and government agencies. When communicating with public, complex technical jargons should be replaced with easily understood terms. In addition, to sustain people's acceptance of NEWater, the NEWater Visitor Centre was set up in early 2003 for the visitors to appreciate the philosophies and technologies used in the production of NEWater. An educational tour was also organized to bring the media from Europe and the United States to observe the various places where water reuse has been practiced for many years. A documentary on the technology of NEWater and the water reuse experience of other countries was also produced and televised.

\subsection{Windhoek, Namibia DPR project}

The city of Windhoek is the capital of Namibia, the most arid country in Sub-Saharan Africa. The Country has a surface area of $825,000 \mathrm{~km}^{2}$ and has a total population of 2.2 million, making it one of the least populated countries in the world. The population of Windhoek is approximately 250,000. Since 1968, Windhoek has been adding highly treated reclaimed water to its drinking water supply system. The blending of reclaimed water with potable water takes place directly in the pipeline that feeds its potable water distribution network.

The reclaimed water meets Namibia Drinking Water Guidelines, World Health Organization Guidelines, and South Africa Rand Guidelines. The project is operated whereby intermediate treated water criteria have to be maintained at certain unit process. Failure to meet these criteria precludes the delivery of final reclaimed water into the distribution system.

\subsubsection{Treatment train processes employed}

The initial Goreangab Treatment Plant, now called the "Old" Goreangab Plant, is shown in Figure 6(a). The old plant went through a series of upgrades with the last upgrade undertaken in 1997 as illustrated on Figure 6(b). The design of the new plant is based on the experience gained over 30 years of water reclamation and reuse, but also includes new processes such as ozonation and ultrafiltration. Before the latter two processes were adopted, they were pilot tested over a 30 -month period to verify the performance with this specific raw water.

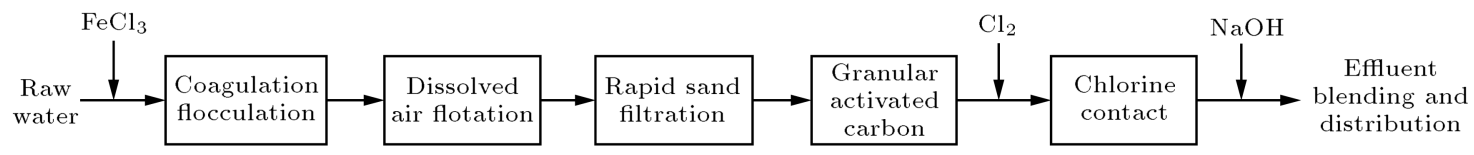

(a)

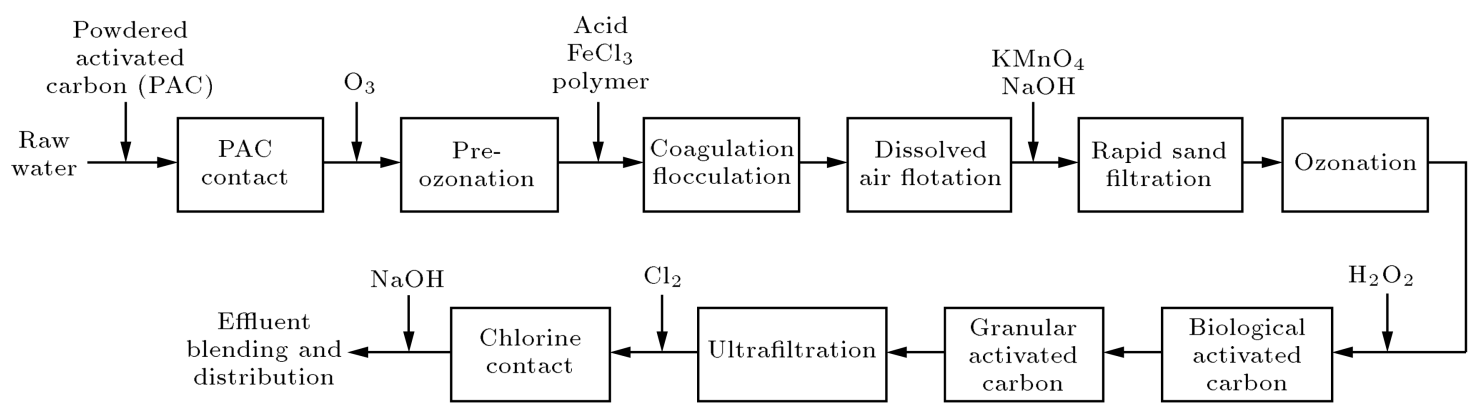

(b)

Figure 6. Process flow diagrams at the Goreangab Water Reclamation Plant in Windhoek, Namibia: (a) Original process flow diagram; and (b) the new 1997 process flow diagram (adapted from du Pisani [22] and Lahnsteiner and Lempert [23]). 


\subsubsection{Lessons learned}

From the Windhoek experience it is evident that highly treated municipal wastewater (reclaimed water) can be reused successfully for potable purposes. In the case of Windhoek, a combination of factors, with the lack of alternative water sources probably the most notable, makes DPR a viable option, even in financial terms. It is, furthermore, evident that the technology exists to produce water reliably that meets all drinking water guidelines and to provide the user with an acceptable level of confidence as to the risk of DPR.

\section{Brief summary of the key implementation challenges for potable reuse}

The important implementation challenges for potable reuse in Iran and elsewhere is introduced in this section. Special additional challenges and barriers that need to be overcome for a successful implementation of potable reuse in Iran are considered in Section 6. The key challenges for the successful implementation of a sustainable PR program include: (1) regulatory considerations, (2) technical issues related to the production of safe drinking water, and (3) public outreach. These three key components are interrelated as illustrated in Figure 7. The success of a PR program in relationship to each of these key challenges is discussed briefly in this section. More detail information about the potable reuse implementation issues may be found in Tchobanoglous et al. [3] and will be presented in the future articles on this series as related to Iran.

\subsection{Regulatory considerations}

The first challenge to the implementation of $\mathrm{PR}$ is the lack of regulations. Based on the knowledge of the authors, at present no standard water quality regulations for $\mathrm{PR}$ have been adopted in Iran. In fact, no standardized regulatory compliance has been established in the United States. However, nine states including state of California, had regulations or guidelines for indirect potable reuse [11]. Currently,

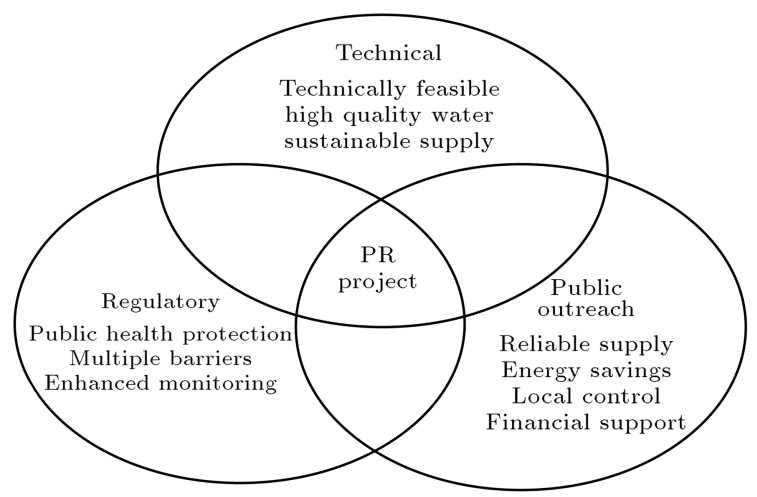

Figure 7. Interrelationship of the key components of a PR program (source: Tchobanoglous et al. [3]). the state of Texas is the only state with existing direct potable reuse projects, which are evaluated and regulated on a case-by-case basis. From public safety point of view, DPR regulations are likely to be similar to IPR regulations; however, additional requirements for DPR may be included, such as added monitoring and operational requirements to account for the lack of a natural environmental buffer and the need for appropriate response times.

Even with lack of regulation for PR in Iran, it is reasonable to assume that the treated water must comply with applicable Iranian laws, regulations, rules, guidelines, or criteria to produce safe drinking water. The existing IPR regulations from individual states in the United States could be adapted initially for the PR program in Iran until the Iranian water authority can develop the regulations of their own.

Regulatory compliance can be accomplished in part by requiring a project report (also called engineering report) that contains a complete description of the proposed PR project. The report should: (1) include the provisions required to address public health issues, such as the control of microbial and chemical constituents; (2) address the Advanced Water Treatment Facility (AWTF) specifically [the report may be independent of the engineering report typically required for a Drinking Water Treatment Facilities (DWTF)]; and (3) define clearly the means for complying with all requirements specified by the regulatory agency.

\subsection{Technical issues}

The second key implementation challenge related to a successful and sustainable PR program is related to technical issues. Some of the elements that make up the technical component of a PR system include the following (Tchobanoglous et al. [20]):

- Source of water supply (e.g., surface water and/or groundwater);

- Source control program for the community or service area where the water will be used, including waste haulers and any tributary wastewater from other jurisdictions;

- Wastewater treatment;

- Advanced water treatment;

- Engineered Storage Buffer (ESB), if needed;

- Drinking water treatment;

- Associated piping and pumping infrastructureincluding the water distribution system, wastewater collection system, and ATW transport system to the location where it will be introduced into the DWTF or distribution network.

Issues to address each of these elements are summarized in Table 8 and will be discussed in more detail in the future articles. 
Table 8. Important issues for each of the elements that composes the technical components of a PR program*.

\begin{tabular}{|c|c|}
\hline Element & Issues/comments \\
\hline Water supply sources & $\begin{array}{l}\text { - Develop an operation plan for blending ATW with alternative water sources. } \\
\text { - If needed, modify existing system to allow for blending and stabilizing the ATW. } \\
\text { - Assess what level of blending, if any, is needed based on quality of ATW and different } \\
\text { water sources. } \\
\text { - Investigate various blend ratios and rationales for target blend rate range. } \\
\text { - Develop an integrated water supply portfolio that includes PR. }\end{array}$ \\
\hline $\begin{array}{l}\text { Source control } \\
\text { program for community } \\
\text { or service area }\end{array}$ & $\begin{array}{l}\text { - Modify pretreatment/source control program, so it is suitable for PR. } \\
\text { - Identify constituents in wastewater that may be difficult to remove or are precursors to } \\
\text { disinfection byproduct formation (depending on treatment technologies used). } \\
\text { - Information is needed on sources and concentrations of selected constituents. } \\
\text { - Include commercial and industrial entities in source control program. } \\
\text { - Develop a program to inform consumers of best practices for home waste disposal. }\end{array}$ \\
\hline Wastewater treatment & $\begin{array}{l}\text { - The better the quality of treated wastewater, the less demand on subsequent advanced } \\
\text { treatment processes. } \\
\text { - Develop and implement influent monitoring systems. } \\
\text { - Determine optimum location, size, and type of flow equalization (inline or offline), and } \\
\text { quantify its benefits on performance and reliability of biological and other treatment } \\
\text { processes. } \\
\text { - Consider how influent monitoring data could be used to adapt treatment operations } \\
\text { depending on variable influent characteristics. } \\
\text { - Quantify benefits of complete nitrification or nitrification and denitrification on } \\
\text { performance of membrance treatment processes used for PR. } \\
\text { - Assess benefits of improvements in biological treatment on removal of both microbial } \\
\text { and chemical constituents. } \\
\text { - Evaluate optimization of conventional processes (i.e., primary, secondary, and tertiary) } \\
\text { to improve overall treatment and reliability of entire system. } \\
\text { - Implement a monitoring scheme to ensure treatment performance for each unit process } \\
\text { and end-of-process validation of water quality. }\end{array}$ \\
\hline $\begin{array}{l}\text { Engineered } \\
\text { storage buffer }\end{array}$ & $\begin{array}{l}\text { - Evaluate need for and type of ESB. } \\
\text { - Define impact of existing monitoring response times, as well as analytical, detection, } \\
\text { and monitoring capabilities, to assess configuration, size, and features of an ESB that } \\
\text { may be required. }\end{array}$ \\
\hline $\begin{array}{l}\text { Drinking water } \\
\text { treatment }\end{array}$ & $\begin{array}{l}\text { - Mix of source water and ATW should not impact water treatment process or adversely } \\
\text { impact finished water quality (see future article on potable reuse in Iran). } \\
\text { - Additional treatment, monitoring, and testing may be required. }\end{array}$ \\
\hline $\begin{array}{l}\text { Engineering infrastructure } \\
\text { (piping and pumping) }\end{array}$ & $\begin{array}{l}\text { - Investigate potential impacts of ATW on drinking water distribution system (e.g., } \\
\text { corrosion issues). }\end{array}$ \\
\hline
\end{tabular}

Notes: ATW: Advanced Treated Water; AWTF: Advanced Water Treatment Facility; DWTF: Drinking Water Treatment Facility; DPR: Direct Potable Reuse; ESB: Engineered Storage Buffer; WWTP: Wastewater Treatment Plant.

* Source: Adapted from Tchobanoglous et al. [20]. 
Table 8. Important issues for each of the elements that composes the technical components of a PR program* (continued).

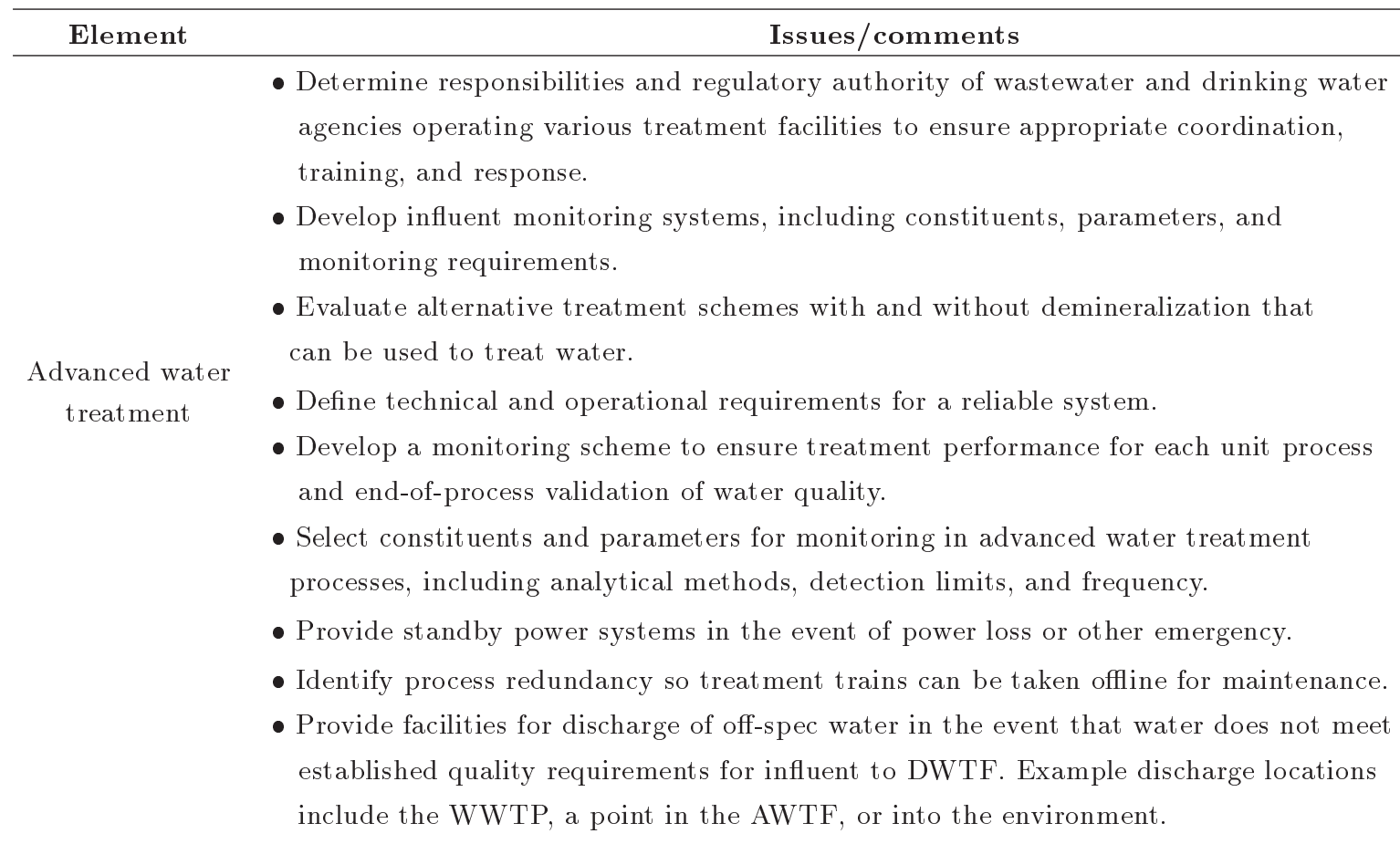

Notes: ATW: Advanced Treated Water; AWTF: Advanced Water Treatment Facility; DWTF: Drinking Water Treatment Facility; DPR: Direct Potable Reuse; ESB: Engineered Storage Buffer; WWTP: Wastewater Treatment Plant.

* Source: Adapted from Tchobanoglous et al. [20].

\subsection{Public outreach}

The third and final general implementation challenge is related to public outreach. A public outreach program is needed to build public confidence and support of the use of reclaimed water produced from ATW as a source of drinking water supply. The public outreach program ideally should launch during the early stages of planning and be maintained throughout the lifetime of the project. Additional information on challenge to overcoming the barrier associated with public perception and public acceptance is presented in Section 6.2. More detail information on public outreach as part of the potable reuse implementation will be presented in the future articles.

\section{Special challenges and barriers on implementation of potable reuse in Iran}

In addition to the general implementation challenges described in Section 5, the implementation of reclaimed water for potable reuse application in Iran, it will be necessary to overcome additional challenges and barriers; particularly at the early stage of the potable reuse program. Additional challenges that must be overcome include, but not limited to: (1) operational and management barriers ensuring high-level water quality, (2) public perception and acceptance barrier, (3) cultural religious factor barrier, and (4) institutional barriers. These barriers are briefly discussed below. Additional details on these special implementation challenges will be presented in a future article on potable reuse in Iran.

\subsection{Operational and management barrier in ensuring high level water quality}

As noted before, the design and construction of centralized wastewater collection and treatment facilities in Iran is fairly new. Because of a lack of long-term experience, Iran may initially have to rely on foreign expertise for technical, construction, operation and monitoring aspects of potable reuse projects. However, to move forward with future water resources management programs including potable reuse, Iran must also focus on developing the required technical knowledge and expertise within the country.

In general, from technical point of view, conventional wastewater treatment systems will need to be designed or modified to optimize their overall performance to enhance the reliability and performance of the AWTFs. Fortunately, the majority of the wastewater treatment plants designed and constructed in Iran are fairly new and many more treatment plants are planned for the future. So, it should not be very difficult to convert the existing wastewater treatment facilities or 
to incorporate some of the advanced treatment features to produce effluent suitable for potable reuse.

\subsection{Public perception and acceptance barriers of potable reuse}

Public perception and acceptance of reclaimed water for indirect and direct potable reuse is an important barrier that should be overcome before initiating potable reuse program in Iran. Over the past decade, public knowledge about reuse has increased, particularly in arid regions of Australia and southwest of the U.S. as these communities see water reuse as a water portfolio option. Iran can learn from these communities while educating the public and increasing their perception and acceptance toward the use of reclaimed water for potable reuse. Public perception with respect to water reuse has been studied with increasing interest in Australia since the mid-1990s [24], and with interest expanding globally since the early 2000s (e.g., [25-30]). The importance of public perception to the successful establishment of water reuse is projects found to be "crucial importance" [31].

\subsubsection{Communication with the public}

Two recent WaterReuse Research Foundation (WRRF) studies have provided valuable and surprising feedback for the water industry about public acceptance related to potable reuse. In one study, it was found that while some staunch opponents are unlikely to change their position, a significant portion of community members might change their opinion to favor reuse when provided clear information [32]. Under this study, participants were provided information related to water reuse, including easy-to-understand technical details and graphics explaining the water purification process. Following this information sharing, most of those who had "minded a little," changed their opinion to "don't mind at all," though many had additional questions. Most who had indicated they "minded a lot" maintained that position. The principal findings from this research were: (1) that information presented to the public needs to be simple enough to understand yet technical enough to be trusted; and (2) that public communications should be treated as a dialogue that avoids technical jargon and acronyms.

\subsubsection{Use of common terminology}

In another study, funded by WRRF, it was found that the use of easy to understand vocabulary when communicating with the public often increased public acceptance of water reuse projects. The term used to describe reclaimed water as part of drinking water supply, the survey respondent indicated that the most reassuring term in describing the water is the use very high quality water without using the "re" prefix (reuse, reclaimed, etc.). At the other end of the spectrum, the terms found least reassuring are the terms most often used by the water industry [33]. In the WRRF study [33], it was also found that most participants preferred the reclaimed water quality be described by the uses for which it is suitable, rather than by a grading system, degree or type of treatment, or type of pollutants removed. It was also noted that the public is less concerned about the source of the drinking water supply than about monitoring and reliability of the safety and taste of their drinking water. Additionally, positive terminology leads to early acceptance of reuse. The water purification plant described in the study appeared to strongly influence people's preference.

\subsection{Cultural and religious factors barrier}

In the WHO guidelines, it is recognized that in addition to technical issues, cultural and religious factors are important to the success of reclaimed water practice for non-potable and potable reuse. WHO reports that societal concerns related to use of untreated human excreta range from abhorrence to acceptance [34]. In Africa, the Americas, and Europe, excreta use is generally regarded with "disaffection", whereas in Asia its use is accepted and in keeping with Chinese and Japanese "traditions of frugality". In Islamic societies, however, direct contact with excrement is abhorred, however its use after treatment would be acceptable if the treatment were to remove impurities. Further, in Islamic countries, it has been judged that wastewater can be used for irrigation provided that the impurities present in raw wastewater are removed [35].

\subsubsection{Use of fatwa to increasing the public acceptance of reuse water}

For safe use of reclaimed water and greater acceptance by public, a fatwa (Rulings of a scholarly opinion on a matter of Islamic law issued by a recognized religious authority in Islam [36]) may be required. However, it is not uncommon for scholars to come to different conclusions regarding the same issue. WHO [35] cites the 1978 Council of Leading Islamic Scholars of Saudi Arabia issuing a fatwa concerning the use of wastewater in Islamic Societies which stated "Impure wastewater can be considered as pure water and similar to the original pure water, if its treatment using advanced technical procedures is capable of removing its impurities with regard to taste, color and smell, as witnessed by honest, specialized and knowledgeable experts."

The following question was posed to the World Fatwa Management and Research Institute website in 2007: "From the Islamic point of view, is the reuse of treated wastewater permissible for irrigation of crops or park areas"? The response reads in part: "If water treatment restores the taste, color, and smell of unclean water to its original state, then it becomes pure and hence there is nothing wrong to use it for irrigation and other useful purposes" [37]. 


\subsubsection{Example of public study acceptance of reuse water in Islamic society}

One example of water reuse project studied in Islamic society is the United States Agency for International Development's (U.S. AID) Reuse in Industry, Agriculture and Landscaping (RIAL), in Jordan. RIAL project have engaged farmers in the successful use of treated wastewater in agricultural crop production. The projects have been successful because they have addressed not only technical and economic, but institutional and cultural issues [38]. The RIAL projects pioneered in developing Water User Association for operation, maintenance, and management of a waste water-based irrigation system in Jordan.

The RIAL projects have shown that reclaimed water can be used safely in agricultural irrigation. Social acceptance of these practices have no doubt been furthered by the understanding of the benefits derived from the reclaimed water and the acceptance of its use in this Islamic culture through the issuances of fatwas allowing water reuse in agriculture. The RIAL projects have demonstrated multiple benefits from well-managed reuse projects including: (1) improved environment as wastewater was no longer discharged into streams and wadis; (2) increased farmers income; and (3) enhanced quality of people's life.

\subsection{Institutional and regulatory barriers}

As previously indicated in Table 2, Section 2.1, because multiple government agencies are now dealing with Iranian water management, conflicting interests must be addressed. The problem of conflicting jurisdictions can partially be resolved through adapting an integrated and sustainable water management plan. In addition, conflicting roles and responsibilities can be reformed and all quantitative and qualitative water management issues can be integrated under one existing agency or a new separate water agency.

At present, based on the knowledge of the authors, there is no national guidance on reclaimed water for potable reuse in Iran. Some water quality criteria have been established in 2010 for wastewater treatment and reuse in irrigation by the Ministry of Energy, Bureau of Engineering and Technical Criteria for Water and Wastewater (http://seso.moe.org.ir). However, the existing water quality criteria must be updated with greater emphasis on public health using the reclaimed water for both non-potable and potable application.

\section{The benefits expected from potable reuse program in Iran}

The application of reclaimed water for potable reuse can provide multiple benefits in different sectors of the society including: (1) public water supply, (2) agriculture, (3) the environment, and (4) sustainability. The benefit derived from each of these areas for Iran is briefly discussed below [40].

\subsection{Public water supply benefits}

Urban water supply demands can be met through a combination of sources and means including: (1) the development of local groundwater and surface water reservoirs, rivers, and lakes; (2) development and implementation of interbasin water transfer systems; (3) desalination of brackish water and seawater; (4) conservation; and (5) potable reuse. Compared to other alternatives, PR can provide a stable, local, supplemental source of water that may be less subject to natural disasters with relatively modest energy requirements. Because the water requirements of cities are greater than wastewater discharges, PR cannot serve as a stand-alone water supply source, but it can be a valuable asset within a broader, integrated, water management portfolio.

\subsection{Agriculture benefits}

As noted previously, nearly 93 percent of the all fresh surface water and groundwater supply in Iran is used in agricultural sector. The withdrawals of all fresh water (excluding power withdrawals) for agriculture uses in the United States is about 65\% [41]. Water that is not exported for urban use can be made available for food production. Non-potable reclaimed wastewater is a valuable asset for agricultural application because it also contains nutrients. Water availability is especially significant during drought periods. Given the projected population growth over the next 25 years, protecting agricultural water supplies for irrigation will become of greater importance, especially in times of drought. Because urban and agricultural users often rely on the same water sources, PR can supplement the amount of water used for potable purposes, which will increase the amount of other waters available for agricultural uses, and reduce competition for water between municipalities and agriculture.

\subsection{Environmental benefits/impacts}

The use of PR may reduce the amount of water imported to urban areas or extracted from groundwater, as well as the amount of wastewater discharged to surface waters. In addition, augmented groundwater that is not extracted can help minimize subsidence from the over drafting of aquifers. Such direct environmental benefits can allow for more effective management of in-stream flows and aquatic ecosystems. For example, reductions in importing water can reduce energy use and its concomitant environmental impacts.

\subsection{Sustainability benefits}

As urban centers continue to grow in Iran, especially along drought-sensitive regions, the stress on existing 
public water supplies will increase. It is already challenging for many of these cities in Iran to develop new local water supplies, as available opportunities are increasingly limited and constrained. At the same time, withdrawing water from one location to another, transporting it to population centers, discharging the untreated and/or partially treated water to the fragile environment is unsustainable. As a consequence, $P R$ is receiving increased attention as a part of the water supply portfolio in many communities, including nonmetropolitan areas facing long-term drought and the depletion of surface water supplies. Vulnerable municipalities, utilities, and agencies must begin to develop the necessary information that will allow potable reuse to become a reality.

\section{Summary}

This article and the future articles on this series are prepared to encourage the consideration of water reuse in Iran; especially for potable reuse. As an integrated water management program is developed for Iran, it is of critical importance that potable reuse be included. By implementing a water reuse program, Iran will be able to expand their available water supply by augmenting existing water sources and providing additional sources of water to assist in meeting both present and future water needs. To move forward with the implementation of water reuse, special attention must be devoted to the barriers that must be overcome. The technical aspects and detail implementation issues will be presented in the future articles.

\section{Acknowledgements}

The authors greatly acknowledge the support and help provided by Dr. Vafai, Editor-in-Chief, and the journal office staff to make this effort a reality.

\section{Nomenclature}

\section{Acronyms}

\section{AWT}

AWTF

BMPs

BOD

$\mathrm{CDPH}$

$\mathrm{CEC}$

$\mathrm{COC}$

CWA

DDW

DPR
Advanced Water Treatment

Advance Water Treatment Facility

Best Management Practices

Biological Oxygen Demand

California Department of Public

Health

Constituents of Emerging Concern

Constituents of Concern

Clean Water Act

Division of Drinking Water (California State Water Resources Control Board) Direct Potable Reuse
DWTF

ESB

FRT

GWRS

HACCP

IPR

LID

MBR

MCL

MCLG

MEED

$\mathrm{MF}$

MOE

NDMA

NF

NPR

NRC

NWRI

O\&M

OCSD

OCWD

PUB

RIAL

RO

SDWA

QRRA

RWC

SWRCB

TDS

TOC

TOrC

TSS

UF

UV

U.S.A.

U.S.AID

U.S. EPA

WHO

WRI

WRF

WRRF

WUA

WWT
Drinking Water Treatment Facility

Engineered Storage Buffer

Failure and Response Time

Groundwater Replenishment System

Hazard Analysis and Critical Control Points

Indirect Potable Reuse

Low Impact Development

Membrane Bioreactor

Maximum Contaminant Level

Maximum Contaminant Level Goal

Middle East Economic Digest

Microfiltration

Minister of Energy (Iran)

N-nitrosodimethylamine

Nanofiltration

Nonpotable Reuse

National Research Council

National Water Research Institute

Operation and Maintenance

Orange County Sanitation District

Orange County Water District

Public Utility Board (Singapore)

Reuse in Industry, Agriculture and landscaping

Reverse Osmosis

Safe Drinking Water Act

Quantitative Relative Risk Assessment

Recycled Water Contribution

State Water Resources Control Board

Total Dissolved Solids

Total Organic Carbon

Trace Organic Constituent (ore trace organic contaminant)

Total Suspended Solid

Ultrafiltration

Ultraviolet

United States of America

United States Agency for Agricultural Development

United States Environmental Protection Agency

World Health Organization

World Resource Institute

Water Research Foundation

Water Reuse Research Foundation

Water User Association

Wastewater Treatment Plant 


\section{Abbreviations for units of measure}

$\begin{array}{ll}\mathrm{bcm} & \text { Billion cubic meter } \\ \mathrm{kg} & \text { Kilogram } \\ \mathrm{km} & \text { Kilometer } \\ \mathrm{kWh} & \text { Kilowatt hour } \\ \mathrm{kWh} / \mathrm{m}^{3} & \text { Kilowatt hour per cubic meter } \\ L / \text { capita } \bullet & \text { Liter per capita per day } \\ \mathrm{m} & \text { Meter } \\ \mathrm{m}^{3} & \text { Cubic meter } \\ \mathrm{MCM} & \text { Million Cubic Meter } \\ \mathrm{MFL} & \text { Million Fibers per Liter } \\ \mathrm{mg} / \mathrm{L} & \text { Milligram per Liter } \\ \mathrm{ng} / \mathrm{L} & \text { Nanograms per Liter (parts per trillion } \\ & \text { (ppt) } \\ \mathrm{NTU} & \text { Nephelometric Turbidity Unit } \\ \mathrm{pCi} / \mathrm{L} & \text { Picocuries per Liter (a measure of } \\ \mathrm{PFU} & \text { radioactivity in water) } \\ \mathrm{ppb} & \text { Plaque Forming Unit } \\ \mathrm{ppm} & \text { Part per billion } \\ \mathrm{ppt} & \text { Parts per million } \\ \mathrm{tonne} & \text { Parts per trillion } \\ \mu \mathrm{g} / L & \text { Metric tonne (1,000 kg) } \\ \mu m & \text { Microgram per Liter } \\ & \end{array}$

\section{References}

1. Dudley, D., Tehran's Dwindling Water Supplies, Middle East Economic Digest (MEED)(currently known as Middle East Business Intelligence), July 16 (2015). http://www.meed.com/sectors/power-and-water/ water/tehrans-dwindling-water-supplies/3211806. article

2. Madani, K. "Water management in Iran: What is causing the looming crisis?", J. Environ. Stu. Sci., 4(3), pp. 315-328 (2014).

3. Tchobanoglous, G., Cotruvo, J., Crook, J., McDonald, E., Olivieri, A., Salveson, A. and Trussell, R.S. "Framework for direct potable Reuse", WaterReuse Research Foundation: Alexandria, VA (2015).

4. Mousavi, S.F. "Agricultural drought management in Iran", in Water Conservation, Reuse, and Recycling: Proceedings of an Iranian-American Workshop, pp. 106-113 (2005).

http://www.nap.edu/catalog/11241.html

5. Alizadeh, A. and Keshavarz, A. "Status of water use in Iran", in Water Conservation, Reuse, and Recycling: Proceedings of An Iranian-American Workshop, pp. 94-105 (2005). http://www.nap.edu/catalog/11241.html.
6. Ministry of Energy (MOE) "Reorganization plan of surface water in south of Tehran", Report TWM/PCR-A-02, Tehran, Iran (2009).

7. Khajehpour, B. "Iran sinks in water crises" (2014). http://www.al-monitor.com/pulse/originals/2014/ 05/iran-water-crisis.html\#

8. Ghazi, I. "Water resources management and planning in Iran", Report to the University of Isfahan (2002).

9. Biswas, A.K. "Deafness to global water crises: Causes and risks", Ambio, 27(6), pp. 492-493 (1998). htt p://www.ircwash.org/sites/default/files/202.398DE-15344.pdf

10. Tajrishy, M. "Wastewater treatment and reuse in Iran: Situation analysis", In Water Conservation, Reuse, and Recycling: Proceedings of an Iranian-American Workshop, pp. 217-229 (2005). http://www.nap.edu/catalog/11241.html

11. U.S. EPA, Guidelines for Water Reuse, EPA/600/ R12/618, Office of Wastewater Management: U.S. Environmental Protection Agency: Washington, DC (2012). http://nepis.epa.gov/Adobe/PDF/P100FS7K.pdf

12. Rodrigo, D., López Calva, E.J. and Cannan, A., Total Water Management, EPA 600/R-12/551, U.S. Environmental Protection Agency, Washington, DC (2012).

13. Mohammadnejad, S. and Tajrishy, M. "Technical and economic evaluation of wastewater reuse of city of Tehran for landscape irrigation", Proceedings of the Second International Civil Engineering Conference, Sharif University of Technology (1998).

14. Razaghi, N., Mansouri, R. and Rouhani, P., Water Reuse (Planning and Programming), NarvanArra, Tehran, Iran (2013).

15. Eslamian, S.A. and Tarkesh Esfahani, S., Water Reuse (Application of Municipal Wastewater Effluent), Akane Danesh Publisher, Esfahan, Iran (2011).

16. Tajrishy, M., Abdolghafoorian, A. and Abrishamchi, A. "Water reuse and wastewater recycling: Solutions to Tehran's growing water crisis", In Global Water: Issues and Insights by R. Quentin Grafton, Paul Wyrwoll, Chris White and David Allendes, ANU Press, The Australian National University, Canberra, Australia (2014).

17. NRC, Water Reuse: Potential for Expanding the Nation's Water Supply Through Reuse of Municipal Wastewater, National Research Council, National Academies Press: Washington, DC (2012). http://www.nap.edu/catalog.php?record_id=13303

18. Hazen, A., Clean Water and How to Get It, 2nd Ed., John Wiley \& Sons: New York (1914).

19. Crook, J., NWRI White Paper on Regulatory Aspects of Direct Potable Reuse in California, National Water Research Institute, Fountain Valley, CA (2010). 
20. Tchobanoglous, G., Leverenz, H., Nellor, M.H. and Crook, J., Direct Potable Reuse: A Path Forward, WateReuse Research Foundation: Alexandria, VA (2011).

21. Burris, D.L. "Groundwater replenishment system 2009 annual report", Prepared for the California Regional Water Quality Control Board, Santa Ana Region (2010)

22. du Pisani, P.L. "Direct reclamation of potable water at Windhoek's Goreangab reclamation plant", in S.J Khan, M.H. Muston, and A.I Schafer (Eds.), Integrated Concepts in Water Recycling 2005, University of Wollongong, Wollongong, Australia, pp. 193-202 (2005).

23. Lahnsteiner, J. and Lempert, G. "Water management in Windhoek/Namibia", In: Proceedings of the IWA Conference, Wastewater Reclamation \& Reuse for Sustainability, Jeju, Korea (2005).

24. Russell, S. and Lux. C. "Water recycling \& the community. Public responses and consultation strategies: A literature review and discussion", Report Oz-AQUAREC WP5, Wollongong, NSW, Australia: University of Wollongong (2006).

25. Jeffrey, P. "Public attitudes to in-house water recycling in England and Wales", Water and Environmental Management Journal, 16(3), pp. 214-217 (2002).

26. Al-Kharouf, S., Al-Khatib, I. and Shaheen, H. "Appraisal of social and cultural factors affecting wastewater reuse in the West Bank", International Journal of Environment and Pollution, 33(1), pp. 3-14 (2008)

27. Ching, L. "Eliminating "yuck": A simple exposition of media and social change in water reuse policies", International Journal of Water Resources Development, 26(1), pp. 111-124 (2010)

28. Domenech, L. and Sauri, D. "Socio-technical transitions in water scarcity contexts: Public acceptance of greywater reuse technologies in the metropolitan area of Barcelona", Resources Conservation and Recycling, 55(1), pp. 53-62 (2010).

29. Haddad, B., Rozin, P., Slovic, P. and Nemeroff, C., The Psychology of Water Reclamation and Reuse: Survey Findings and Research Roadmap, WaterReuse Foundation, Arlington, VA (2010).

30. Nellor, M.H. and Millan, M., Public and Political Acceptance of Direct Potable Reuse, WateReuse California, Sacramento, CA (2010).

31. Marks, J., Martin, B. and Zadoroznyj, M. "How Australians order acceptance of recycled water: National baseline data", Journal of Sociology, 44(1), pp. 83-99 (2008).

32. WateReuse Research Foundation (WRRF), Talking About Water: Vocabulary and Images that Support Informed Decisions About Water Recycling and Desalination, WRF- 07-03. WateReuse Research Foundation. Alexandria, VA (2011).

33. WateReuse Research Foundation (WRRF), The Effect of Prior Knowledge of 'Unplanned' Potable Reuse on the Acceptance of 'Planned' Potable Reuse, WRF-0901.WateReuse Research Foundation. Alexandria, VA (2012).

34. WHO. "Guidelines for the safe use of wastewater, excreta and greywater", Wastewater Use in Agriculture, II (2006a). 9241546832_eng.pdf

35. WHO. "Guidelines for the safe use of wastewater, excreta and greywater", Excreta and GreyWater Use in Agriculture, IV (2006b). 9241546859_eng.pdf

36. About Islam "What is fatwa?" Website accessed January (2016).

<http://islam.about.com/od/law/g/fatwa.htm>.

37. INFAD, Wastewater Treatment, World Fatwa Management and Research Institute", Islamic Science University of Malaysia, Retrieved on March (2012) http://infad.usim.edu.my

38. U.S. AID "Water reuse for industry, agriculture and landscaping (RIAL) project, Task 1: Reuse reclaimed water in irrigation for both agriculture and landscaping", USAID, Jordan (2008).

39. Jordan Geography and Environment (2012) "Jordan's water shortage", Retrieved on January (2016). http://www.kinghussein.gov.jo/geo_env4.html

40. Schroeder, E., Tchobanoglous, G., Leverenz, H.L. and Asano, T., Direct Potable Reuse: Benefits for Public Water Supplies, Agriculture, the Environment, and Energy Conservation, National Water Research Institute: Fountain Valley, CA (2012).

http://www.nwriusa.org/documents/ NWRIWhitePaperDPRBenefitsJan2012.pdf

41. Maupin, M.A., Kenny, J.F., Hutson, S.S., Lovelace, K.K., Barber, N.L. and Linsey, K.S., Estimated Use of Water in the United States in 2010, U.S. Geological Survey Circular 1405, U.S. Department of the Interior, pp.1-56 (2014). http://pubs.usgs.gov/circ/1405/

\section{Biographies}

Masoud Kayhanian is Research Professor Emeritus in the Department of Civil and Environmental Engineering at the University of California, Davis, where he performed research and taught for 25 years. He also served as the Director of UC Davis HighSolid Bio-Gasification Project from 1991-1996 and the Associate Director of Center for Environmental and Water Resources Engineering from 2003-2009. His research interests are in the areas of surface water quality, innovative stormwater runoff treatment, water reuse, fate and transport of pollutants in the environment, and bioconversion of waste materials into energy. He has authored or co-authored over 185 technical publications including four book chapters.

George Tchobanoglous is Professor Emeritus in the Department of Civil and Environmental Engineering at the University of California, Davis, where he taught 
for 35 years. His research interests are in the areas of wastewater treatment, water reuse, wastewater management for small and decentralized wastewater management systems, and solid waste management. He is a Past President of the Association of Environmental
Engineers and Science Professors. He is a member of the National Academy of Engineering, WEF Fellow, and a registered engineer. He has authored or coauthored over 550 technical publications including 23 textbooks and 8 reference works. 